\title{
Sorting out the Value of Cruciferous Sprouts as Sources of Bioactive Compounds for Nutrition and Health
}

\author{
Ángel Abellán ${ }^{\dagger}$, Raúl Domínguez-Perles ${ }^{+} \mathbb{D}$, Diego A. Moreno $\mathbb{D}^{\mathbb{D}}$ and Cristina García-Viguera * \\ Phytochemistry and Healthy Foods Lab, Research Group on Quality, Safety and Bioactivity of Plant Foods, \\ Department of Food Science and Technology, CEBAS (CSIC), Campus Universitario de Espinardo 25, \\ 30100 Murcia, Spain; avictorio@cebas.csic.es (Á.A.); rdperles@cebas.csic.es (R.D.-P.); \\ dmoreno@cebas.csic.es (D.A.M.) \\ * Correspondence: cgviguera@cebas.csic.es; Tel.: +34-968-396-200 (ext. 6304) \\ + These authors contributed equally to this work.
}

Received: 16 January 2019; Accepted: 13 February 2019; Published: 19 February 2019

\begin{abstract}
Edible sprouts with germinating seeds of a few days of age are naturally rich in nutrients and other bioactive compounds. Among them, the cruciferous (Brassicaceae) sprouts stand out due to their high contents of glucosinolates (GLSs) and phenolic compounds. In order to obtain sprouts enriched in these phytochemicals, elicitation is being increasing used as a sustainable practice. Besides, the evidence regarding the bioavailability and the biological activity of these compounds after their dietary intake has also attracted growing interest in recent years, supporting the intake of the natural food instead of enriched ingredients or extracts. Also, there is a growing interest regarding their uses, consumption, and applications for health and wellbeing, in different industrial sectors. In this context, the present review aims to compile and update the available knowledge on the fundamental aspects of production, enrichment in composition, and the benefits upon consumption of diverse edible cruciferous sprouts, which are sources of phenolic compounds and glucosinolates, as well as the evidence on their biological actions in diverse pathophysiological situations and the molecular pathways involved.
\end{abstract}

Keywords: Brassicaceae; elicitation; growing conditions; broccoli; radish; kale pak choi; isothiocyanates

\section{Introduction}

In the last decades, a growing interest concerning the implications of diet and physical activity on health has occurred in society. This interest lies in the expansion of life expectancy as well as in the improvement in quality of life, and this has led to interventions based on the incorporation of new healthy foods in the human diet. These new foods are envisaged to constitute a valuable source of bioactive healthy nutrients and non-nutrients that would contribute to delaying the onset of a number of chronic and disabling diseases as well as reducing their incidence and severity. In this sense, consumers are demanding a diversified range of foods that provide health benefits and contribute to well-being. For the consecution of this objective, a wide range of plants, crops, and foods have been studied and characterized throughout the recent decades regarding their potential to exert effects on health, according to their nutritional content and bioactive phytochemical composition. Also, many works have paid attention to the bioaccessibility, bioavailability, and bioactivity which will allow, in the near future, validation of their use in the design of new functional ingredients and foods [1].

In this regard, edible sprouts represent a valuable source of diverse micronutrients (vitamins, minerals, and amino acids), macronutrients (proteins, low in carbohydrates, and a high content of dietary fiber), and plant secondary metabolites (mainly phenolic compounds and glucosinolates 
(GLSs)). Due to this composition, edible sprouts are a valuable vehicle and opportunity to impact health, delivering beneficial bioactive compounds once incorporated in the diet on a regular basis.

From a commercial point of view, a broad spectrum of sprouts and sprouting seeds is available including, but not limited to, soybean, alfalfa, broccoli, radishes, kale, watercress, and peas. This type of fresh product is gaining interest, not only in the field of gourmet and elite cooking or in dedicated nutrition (e.g., vegetarians and health conscious consumers), but also (and consequently) in the food industry, boosted by interest in sprouts as a source of nutrients and healthy secondary metabolites with a really short production time (5-10 days, depending on species or varieties) [2].

Within the current diversity of sprouts and germinates, cruciferous types (which includes sprouts of Brassicaceae, like broccoli, radish, kale, mustards, radishes, or wasabi) are noticed because of their high content of micronutrients, nitrogen-sulfur compounds (glucosinolates (GLSs) and their derivatives, isothiocyanates (ITCs), and indoles) and phenolic compounds (mainly phenolic acids, flavonols, and anthocyanins) [3-5].

This review aims to compile and update the available knowledge on the fundamental aspects of production [6], enrichment in composition, and benefits upon consumption of diverse edible raw sprouts as suitable sources of (poly)phenols and GLSs, as well as the currently available evidence on their biological actions in diverse pathophysiological situations and the molecular pathways involved. In this sense, it has been noticed that there is a close linkage between the bioactive composition of cruciferous sprouts and their capacity to act as "phytopharmaceutics" with a valuable contribution to human health.

\section{Bioactive Secondary Metabolites in Edible Cruciferous Sprouts}

As mentioned above, cruciferous sprouts contain non-nutrient/health-promoting compounds, such as diverse types of glucosinolates and phenolic compounds [5]. The biological activity developed by these compounds is mainly due to their antioxidant capacity, which could lower the deleterious consequences of excessively high levels of reactive oxygen species (ROS) in cells and, thus, decrease oxidative stress (OS) by providing cells with molecular tools to combat the imbalance between the production of ROS and the capacity to modulate the redox balance. These properties have direct effects on a number of cellular processes triggered by ROS, which are related to inflammation and oxidative reactions on DNA, proteins, and cell lipids [7]. In addition, to provide further molecular tools to cells to lower OS, many bioactive phytochemicals present in edible sprouts display biological functions that are crucial for the prevention of carcinogenesis processes and other chronic diseases [1] (Table 1).

Table 1. The main bioactive phytochemicals and health promoting activities of diverse raw edible sprouts.

\begin{tabular}{|c|c|c|c|}
\hline Edible Sprout & Main Bioactive Compounds & $\begin{array}{c}\text { Main Bioactivities } \\
\text { Associated with Sprout } \\
\text { Consumption }\end{array}$ & References \\
\hline \multirow{4}{*}{$\begin{array}{c}\text { Broccoli } \\
\text { (Brassica oleracea var. } \\
\text { Italica) }\end{array}$} & $\begin{array}{l}\text { Flavonoids } \\
\text { Quercetin, kaempferol, and } \\
\text { flavonol glycosides }\end{array}$ & \multirow{4}{*}{$\begin{array}{l}\text { Cancer risk }(\downarrow) \\
\text { Degenerative diseases }(\downarrow) \\
\text { Obesity-related metabolic } \\
\text { disorders }(\downarrow) \\
\text { Allergic nasal symptoms }(\downarrow) \\
\text { Inflammation }(\downarrow) \\
\text { Pain }(\downarrow) \\
\text { Antioxidant capacity }(\uparrow)\end{array}$} & \multirow{4}{*}[5,8]{} \\
\hline & $\begin{array}{l}\text { Phenolic acids } \\
\text { Chlorogenic, sinapic, and } \\
\text { ferulic acid derivatives }\end{array}$ & & \\
\hline & $\begin{array}{l}\text { Glucosinolates } \\
\text { Glucoraphanin, glucoiberin, } \\
\text { glucoraphenin, glucobrassicin, } \\
\text { 4-hydroxyglucobrassicin, } \\
\text { 4-methoxyglucobrassicin, and } \\
\text { neoglucobrassicin }\end{array}$ & & \\
\hline & $\begin{array}{l}\text { Isothiocyanates } \\
\text { Sulphoraphane, iberin, and } \\
\text { indole-3-carbinol }\end{array}$ & & \\
\hline
\end{tabular}


Table 1. Cont.

\begin{tabular}{|c|c|c|c|}
\hline \multirow{4}{*}{$\begin{array}{l}\text { Radish } \\
\text { (Raphanus satious L.) }\end{array}$} & $\begin{array}{l}\text { Flavonoids } \\
\text { Quercetin }\end{array}$ & \multirow{4}{*}{$\begin{array}{l}\text { Risk of cancer }(\downarrow) \\
\text { Heart disease }(\downarrow) \\
\text { Diabetes }(\downarrow) \\
\text { Antioxidant capacity }(\uparrow)\end{array}$} & \multirow{4}{*}{ [9] } \\
\hline & $\begin{array}{l}\text { Phenolic acids } \\
\text { Ferulic, caffeic and } p \text {-coumaric } \\
\text { acids, and derivatives }\end{array}$ & & \\
\hline & $\begin{array}{l}\text { Glucosinolates } \\
\text { Glucoraphenin, } \\
\text { dehydroerucin, glucobrassicin, } \\
\text { and 4-methoxyglucobrassicin }\end{array}$ & & \\
\hline & $\begin{array}{l}\text { Isothiocyanates } \\
\text { Sulforaphene, sulforaphane, } \\
\text { and indole-3-carbinol }\end{array}$ & & \\
\hline \multirow[b]{3}{*}{$\begin{array}{c}\text { Kale } \\
\text { (Brassica oleracea var. } \\
\text { acephala) }\end{array}$} & $\begin{array}{l}\text { Flavonoids } \\
\text { Quercetin and cyanidin }\end{array}$ & \multirow[b]{3}{*}{$\begin{array}{l}\text { Risk of cancer }(\downarrow) \\
\text { Heart disease }(\downarrow) \\
\text { Diabetes }(\downarrow) \\
\text { Antioxidant capacity }(\uparrow)\end{array}$} & \multirow[b]{3}{*}{ [10] } \\
\hline & $\begin{array}{l}\text { Phenolic acids } \\
\text { Chlorogenic and ferulic acids }\end{array}$ & & \\
\hline & $\begin{array}{l}\text { Glucosinolates } \\
\text { Glucoraphanin, glucoiberin, } \\
\text { gluconapin, gluconasturtin, } \\
\text { progoitrin, gluconapin, } \\
\text { gluconapoleiferin, sinigrin, } \\
\text { glucobrassicin, } \\
\text { 4-hydroxyglucobrassicin, } \\
\text { 4-methoxyglucobrassicin, and } \\
\text { neoglucobrassicin }\end{array}$ & & \\
\hline \multirow{3}{*}{$\begin{array}{c}\text { Pak choi } \\
\text { (Brassica rapa var. } \\
\text { chinensis) }\end{array}$} & $\begin{array}{l}\text { Flavonoids } \\
\text { Kaempferol, quercetin, and } \\
\text { isorhamnetin glucosides }\end{array}$ & \multirow{3}{*}{$\begin{array}{l}\text { Risk of cancer }(\downarrow) \\
\text { Heart disease }(\downarrow) \\
\text { Diabetes }(\downarrow) \\
\text { Antioxidant capacity }(\uparrow)\end{array}$} & \multirow{3}{*}[10,11]{} \\
\hline & $\begin{array}{l}\text { Phenolic acids } \\
\text { Ferulic, sinapic, caffeic, and } \\
\text { p-coumaric acids, and } \\
\text { derivatives }\end{array}$ & & \\
\hline & $\begin{array}{l}\text { Glucosinolates } \\
\text { Gluconapin, glucoalyssin, } \\
\text { gluconasturtin, progoitrin, } \\
\text { glucobrassicin, } \\
\text { 4-hydroxyglucobrassicin, } \\
\text { 4-methoxyglucobrassicin, and } \\
\text { neoglucobrassicin }\end{array}$ & & \\
\hline
\end{tabular}

\subsection{Phenolic Compounds in Cruciferous Sprouts}

Phenolic compounds are a large class of plant secondary metabolites, sourced exclusively from the shikimate-derived phenylpropanoid and/or the polyketide pathway(s), which feature more than one phenolic ring and are devoid of any nitrogen-based functional group in their most basic structural expression. They are mainly represented by flavonoids and phenolic acids of hydroxycinnamic origin in cruciferous sprouts [12] (Table 1). The diversity of structures is related to a variety of properties associated with specific roles in plants, hence their specific distribution.

The physiological relevance of the phenolic compounds in foods and the cruciferous sprout intake may contribute to the positive effects on health of the phenolic metabolites on the different mode of actions that have been widely studied and reported in literature [13].

The formation of a specific bioactive compound depends on diverse variables, like the stress suffered by sprouts during germination, the environmental conditions, or the nutrient supply [12]. In this sense, cruciferous vegetables and their sprouts feature a similar (poly)phenolic profile, composed mainly by phenolic acid derivatives (e.g., sinapic and ferulic acid glycosylated derivatives and 
caffeoyl-quinic acids) and glycosylated flavonoids (mainly kaempferol and quercetin derivatives, with few or absent isorhamnetins) [14]. When it comes to colored flavonoids, broccoli, radishes, cabbages, and kale sprouts are rich in anthocyanins-most of them highly acylated and glycosylated forms of cyanidin $[3,15,16]$ (Table 1). The interest in anthocyanins has risen in recent years, because of their role in the control of diseases like obesity or diabetes and the possibility of them acting positively on brain function [17].

\subsection{Glucosinolates in Cruciferous Sprouts}

The GLSs, which are essentially unique to Brassicaceae, are secondary metabolites of the stress response, which are located in intact stable forms in plant cells. The general structure of GLSs consists of a glucose molecule linked to a thiohydroximate-O-sulfonate and an amino acid [18]. Attending to this cited amino acid group, GLSs are classified into three groups: aliphatic (including a methionine, isoleucine, leucine, or valine derived moiety in their structure), indole (including a tryptophan derived moiety in their structure), and aromatic (including a phenylalanine or tyrosine derived moiety in their structure) [5]. However, GLSs are not biologically active molecules, but the substrate of hydrolysis reactions after the rupture of plant tissues and the contact with the hydrolysis enzyme myrosinase, a plant thioglucosidase normally located into vacuoles in a specialized cell type named myrosin cells. Through this reaction, myrosinase catalyzes the hydrolysis of GLSs to ITCs or indoles, as well as nitriles and epithionitriles [19], depending on the $\mathrm{pH}$, the presence of Fe and epithiospecifier proteins, and other conditions The ITCs are generally produced under physiological $\mathrm{pH}$ conditions $(\mathrm{pH}$ 6.0-7.0) and are widely known as chemo-preventive and detoxifying agents [20]. The isothiocyanates (ITCs) and thiocyanates present a sulfide group that is united to the carbon with a double (ITCs) or a triple bond (thiocyanates). On the other hand, nitriles lose the sulfide group and in the presence of $\mathrm{Fe}$ molecules, can be metabolized to epithionitrile [21].

Brassicaceae sprouts are of special interest as dietary sources of GLSs (Table 1), being glucoraphanin (GR) the most abundant one, and its derived, sulforaphane (SFN), the most abundant ITC in broccoli sprouts. The SFN needs the presence of glutathione (GSH) to be conjugated and to generate the derivative accessible to cells, where it develops its biological functions as a SFN-GSH derivative [22]. Sulforaphane is responsible for the modulation of a number of molecular pathways in cells, which is the basis of its health-promoting attributions. Another GLS present in cruciferous sprouts (e.g., broccoli and kale) at concentrations that allow their interesting biological activity to be seen in vivo is glucoiberin (GIB) (precursor of the ITC iberin, IB), which has beneficial effects on oxidative stress and cancer prevention [2].

Apart from broccoli, red radish sprouts contain high concentrations of glucoraphasatin (4-methyl thio-3-butenyl) and glucoraphenin, which are its major GLSs [23]. Glucoraphenin is hydrolyzed to the ITC sulphoraphene (SFE), a bioactive compound that contributes to the lowering of oxidative stress in cells as well as providing antimutagenic activity against diverse malignant cell types [5].

In addition, cruciferous sprouts have an important presence of indole GLSs. In this sense, indol-3-carbinol may act as a chemopreventive agent which avoids the proliferation of diverse cancer cell lines, acting over a wide range of signaling pathways (hormonal homeostasis, cell cycle progression, and cell proliferation) [24].

Detailed aspects of the health promoting bioactivity of the GLSs, ITCs, and indoles is discussed in more detail in Section 4 ("The Challenges of Including Cruciferous Sprouts in Balanced diets and Personalized Nutrition").

\section{Elicitation of Brassicaceae Sprouts to Enhance the Content of Bioactive (Poly)phenols and Glucosinolates}

The production of edible sprouts allows the modification of certain pre- and post-harvest conditions to try to improve the production of secondary metabolites, such as GLSs or phenolic acids. Indeed, nowadays, elicitation has been employed in agronomic production to increase the 
expression of specific genes of interest in plants [25]. The elicitation alternatives that could induce stress in the plants vary from the modification of the abiotic factors affecting sprout growth in the chamber, such as temperature, humidity, and the light intensity/period, to the use of specific biotic elicitors, like plant hormones (methyl-jasmonate and ethylene, among others) or amino acids (methionine) [26]. In this context, elicitors can be classified as biotics (plant hormones, proteins, natural toxins, oligosaccharides, lipopolysaccharides, polysaccharides, or extracts with essential oils) and abiotics (minerals, chemical elements, physical damage, or benzothiadiazole) [6]. Moreover, seed priming before the exogenous elicitation has also been described as modulating the response of the sprouts [6]. Nowadays, these elicitation practices are extensively used to implement the production of edible sprouts, while new emergent agro-technologies, like the use of light-emitting diode (LED) lights to elicit secondary metabolites ((poly)phenols and GLSs) in edible sprouts, has been less explored. In this regard, Baenas et al. (2014) [6] clustered many techniques and their effects on the content of bioactive (poly)phenols and GLSs or the transcription of specific genes in diverse raw edible sprouts, and updated information is presented in Table 2.

The elicitation with $\mathrm{Mg}$ (50-300 $\mathrm{mg} / \mathrm{L})$ enhanced the production and concentration of total phenolics in radish sprouts when applied at a concentration of $300 \mathrm{mg} / \mathrm{L}$, although regarding broccoli sprouts, it reduced the content of total phenolics when applied at $50 \mathrm{mg} / \mathrm{L}$ [27] (Table 2). Besides, the cited study analyzed the influence of different $\mathrm{Mg}$ dosages on the defense capacities of broccoli and radish against OS, and significant modifications of the antioxidant capacity were demonstrated with augmented activity of the major antioxidant enzymes (catalase (CAT), gluatathione reductase (GR), and ascorbate peroxidase (APX)). Specifically, the activity of CAT in Mg-enriched sprouts increased in broccoli (up to 46.7\% higher), but decreased in radish sprouts (by 1.5-20.0\%). On the other hand, the activity of GR increased in radish sprouts (32.0-96.0\% higher), while it decreased in broccoli (14.8-40.7\% lower). The APX activity increased in broccoli sprouts, but just at intermediate concentrations (50 and $100 \mathrm{mg} / \mathrm{L}$ ), while in radish sprouts, it significantly decreased (7.6-24.1\%). These enzymes are key to the antioxidant capacity of the plants. However, currently, it is not clear how the improvement in the reduction of ROS, as a consequence of the elicitation of $\mathrm{Mg}$, is a positive effect for plants, and further research is required (Table 2).

Table 2. Compounds of interest in edible sprouts through different elicitors (update from original table of Baenas et al., 2014 [6]).

\begin{tabular}{|c|c|c|c|c|c|}
\hline Raw Edible Sprout & Elicitor Treatment & $\begin{array}{c}\text { Elicitor } \\
\text { Classification }\end{array}$ & Application & $\begin{array}{l}\text { Target Compound and } \\
\text { Increase }\end{array}$ & Reference \\
\hline $\begin{array}{c}\text { Broccoli sprouts } \\
\text { (Brassica oleracea) } \\
\text { (7 days of growth) }\end{array}$ & $\begin{array}{l}\text { Sucrose, fructose, } \\
\text { and glucose } \\
(146 \mathrm{mM})\end{array}$ & Biotic elicitor & $\begin{array}{l}\text { In } 0.5 \% \text { agar media } \\
\text { for } 5 \text { days after } \\
\text { sowing seeds }\end{array}$ & Total anthocyanins $(10.0 \%)$ & [28] \\
\hline $\begin{array}{c}\text { Broccoli sprouts } \\
\text { (Brassica oleracea) } \\
\text { (7 days of growth) }\end{array}$ & $\begin{array}{l}\text { Sucrose and } \\
\text { mannitol } \\
(176 \mathrm{mM})\end{array}$ & Biotic elicitor & $\begin{array}{c}\text { Hydroponic } \\
\text { system for } 5 \text { days } \\
\text { after sowing seeds }\end{array}$ & $\begin{array}{l}\text { Total anthocyanins }(40.0 \%) \\
\text { and phenolics }(60.0 \%) \\
\text { Total glucosinolates }(50.0 \%)\end{array}$ & [28] \\
\hline
\end{tabular}


Table 2. Cont.

\begin{tabular}{|c|c|c|c|c|c|}
\hline Raw Edible Sprout & Elicitor Treatment & $\begin{array}{c}\text { Elicitor } \\
\text { Classification }\end{array}$ & Application & $\begin{array}{l}\text { Target Compound and } \\
\text { Increase }\end{array}$ & Reference \\
\hline $\begin{array}{l}\text { Broccoli sprouts } \\
\text { (Brassica oleracea) }\end{array}$ & Sucrose (146 mM) & Biotic elicitor & $\begin{array}{l}\text { In } 0.5 \% \text { agar media } \\
\text { for } 5 \text { days after } \\
\text { sowing }\end{array}$ & Total GLS (2.0-fold) & [28] \\
\hline $\begin{array}{l}\text { Broccoli sprouts } \\
\text { (Brassica oleracea) } \\
\text { (7 days of growth) }\end{array}$ & $\operatorname{Mg}\left(300 \mathrm{mg} \mathrm{L}^{-1}\right)$ & Abiotic elicitor & $\begin{array}{l}\text { Suplementation } \\
\text { with } \mathrm{MgSO}_{4}\end{array}$ & $\begin{array}{l}\text { Increase of total ascorbic acid } \\
\text { contain }(29.1-44.5 \%)\end{array}$ & [27] \\
\hline $\begin{array}{l}\text { Radish sprouts } \\
\text { (raphanistrum subsp. } \\
\text { sativus) } \\
\text { (12 days of growth) }\end{array}$ & $\begin{array}{l}\text { MeJA }(100 \mu \mathrm{M}) \\
\text { Light }\end{array}$ & $\begin{array}{l}\text { Biotic elicitor } \\
\text { (plant } \\
\text { hormones-MeJA-) } \\
\text { Abiotic elicitor }\end{array}$ & $\begin{array}{l}\text { Treatment with } \\
\text { MeJA in growth } \\
\text { chamber under } \\
\text { light }\end{array}$ & $\begin{array}{l}\text { Glucoraphanin (1.5-fold) } \\
\text { Glucoerucin (1.6-fold) } \\
\text { Glucotropaeolin (1.3-fold) } \\
\text { 4-hydroxyglucobrassicin } \\
\text { (4.4-fold) } \\
\text { Pergonidin (1.7-fold) } \\
\text { Cyanidin (2.0-fold) }\end{array}$ & {$[30]$} \\
\hline $\begin{array}{c}\text { Radish sprouts } \\
\text { (raphanistrum subsp. } \\
\text { sativus) } \\
\text { (7 days of growth) }\end{array}$ & $\operatorname{Mg}\left(300 \mathrm{mg} \mathrm{L}^{-1}\right)$ & Abiotic elicitor & $\begin{array}{l}\text { Supplementation } \\
\text { with } \mathrm{MgSO}_{4}\end{array}$ & $\begin{array}{l}\text { Phenolic compounds } \\
(13.9-21.7 \%)\end{array}$ & [27] \\
\hline $\begin{array}{l}\text { Radish sprouts } \\
\text { (raphanistrum subsp. } \\
\text { sativus) }\end{array}$ & $\mathrm{NaCl}(100 \mathrm{mM})$ & Abiotic elicitor & $\begin{array}{l}\text { In } 0.5 \% \text { agar media } \\
\text { for } 3.5 \text { and } 7.0 \text { days } \\
\text { after sowing }\end{array}$ & $\begin{array}{l}\text { Total phenolics ( } 30 \text { and } 50 \% \text { in } \\
5 \text { and } 7 \text { day-old sprouts, } \\
\text { respectively) } \\
\text { Total GLS ( } 50 \% \text { and } 120 \% \text { in } 5 \\
\text { and } 7 \text { day-old sprouts, } \\
\text { respectively) }\end{array}$ & [31] \\
\hline $\begin{array}{l}\text { Pak Choi sprouts } \\
\text { (rapa subsp. chinensis) }\end{array}$ & $\begin{array}{c}\text { Application of } \\
\text { different } \\
\text { wavelengths of } \\
\text { LED light (white, } \\
\text { blue, and red) }\end{array}$ & Abiotic elicitor & $\begin{array}{l}\text { Medium of perlite } \\
\text { for } 5 \text { days in } \\
\text { darkness and } 18 \mathrm{~h} \\
\text { at the different } \\
\text { wavelengths }\end{array}$ & $\begin{array}{l}\text { Total carotenoid content } \\
\text { (12.1\% and } 9.2 \% \text { with white } \\
\text { light (respect to blue and red } \\
\text { light, respectively) }\end{array}$ & {$[25]$} \\
\hline $\begin{array}{c}\text { Kale Sprouts } \\
\text { (oleracea var. sabellica) }\end{array}$ & $\begin{array}{c}\text { Application of } \\
\text { different light } \\
\text { wavelengths } \\
(470,660, \text { and } 730 \\
\mathrm{nm})\end{array}$ & Abiotic elicitor & $\begin{array}{l}\text { Seeds stratified for } \\
2 \text { days, exposed to } \\
\text { light for } 1 \mathrm{~h}, \\
\text { exposed to } \\
\text { darkness for } \\
\text { between } 1 \text { and } 3 \\
\text { days and later, the } \\
\text { specific light } \\
\text { treatment }\end{array}$ & Total GLS content $(31.7 \%)$ & {$[32]$} \\
\hline $\begin{array}{l}\text { Radish, Chinese kale } \\
\text { and pak choi sprouts } \\
\text { ( } 3 \text { days of growth) }\end{array}$ & 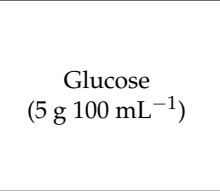 & Biotic elicitor & $\begin{array}{c}\text { Hydroponic } \\
\text { system for } 3 \text { days } \\
\text { after sowing seeds }\end{array}$ & $\begin{array}{l}\text { Total phenolics }(20.0 \%), \\
\text { gluconapin }(150.0 \% \text { and } 60.0 \% \\
\text { in Chinese kale and pak choi, } \\
\text { respectively), } \\
\text { glucobrassicanapin (110-fold } \\
\text { in pak choi) }\end{array}$ & [33] \\
\hline $\begin{array}{l}\text { Different Brassica } \\
\text { sprouts (broccoli, } \\
\text { turnip, and rutabaga) }\end{array}$ & $\begin{array}{c}\text { MeJA }(25 \mu \mathrm{M}) \\
\text { JA }(150 \mu \mathrm{M}) \\
\text { Sucrose }(146 \mathrm{mM})\end{array}$ & $\begin{array}{c}\text { Biotic elicitors } \\
\text { (Sucrose and plant } \\
\text { hormones-MeJA } \\
\text { and JA) }\end{array}$ & $\begin{array}{l}\text { Sprayed for } 5 \text { days } \\
\text { before harvest }\end{array}$ & $\begin{array}{l}\text { Total GLS } \\
(>50 \% \text {, broccoli; }>20.0 \% \\
\text { turnip; }>100.0 \% \text { rutabaga })\end{array}$ & [34] \\
\hline $\begin{array}{c}\text { Radish sprouts } \\
\text { (raphanistrum subsp. } \\
\text { sativus) } \\
\text { (8 days of growth) }\end{array}$ & $\begin{array}{c}\text { MeJA }(25 \mu \mathrm{M}) \\
\text { SA }(100 \mu \mathrm{M}) \\
\text { Glucose }(277 \mathrm{mM})\end{array}$ & $\begin{array}{c}\text { Biotic elicitors } \\
\text { (glucose and plant } \\
\text { hormones-MeJA } \\
\text { and JA) }\end{array}$ & $\begin{array}{l}\text { Sprayed for } 5 \text { days } \\
\text { before harvest }\end{array}$ & Total GLS (20.0\%) & [34] \\
\hline
\end{tabular}

Genes: CYP97A3: cytochrome P450 97A3; CYP97C1: cytochrome P450 97C1; $\beta L C Y$ : $\beta$-cyclase; $\varepsilon L C Y$ : $\varepsilon$-cyclase; $\beta$-OHASE1: $\beta$-carotene hydroxylase 1; PDS: phytoene desaturase; PSY: phytoene synthase; VDE: violaxanthin de-epoxidase; ZEP: zeaxanthin epoxidase. GLS: glucosinolates; JA: jasmonate or jasmonic acid; LED: diode electric light; MeJA: methyl jasmonate; Met, methionine; Mg, magnesium; SA, salicylic acid; Trp, tryptophan. 
It is also important to mention that the elicitation with plant hormones can be effective to modify the secondary metabolism of higher plants. In this regard, methyl jasmonate (MeJA) and the free acid associated jasmonic acid (JA) are regulators with key influences on the diverse steps of cellular pathways involved in the development of Brassicaceae sprouts in the stages of seed germination, root growth, fertility, and senescense, among others. However, the succes of the elicitation with MeJA and its influence on the secondary metabolism depends on an array of factors like the presence of induced light [35] or the combination with other elicitors, like polysaccharides [34]. In this sense, Al-Dabhy et al., 2015 demonstrated that light has a decisive influence on the production of GLSs and anthocyanins in radish sprouts at different developmental stages. In fact, when grown under light absence conditions with and without MeJA elicitation, a less intense augmentation of anthocyanins and most GLSs was observed relative to that produced with exposition to light. Besides, the application of MeJA to radish sprouts with induced light showed significant increases mainly represented by glucoraphanin (1.5-fold), glucoerucin (1.6-fold), glucotropaeolin (1.3-fold), 4-hydroxyglucobrassicin (4.4-fold), pelargonidin (1.7-fold), and cyanidin (2.0-fold) (Table 2). Finally, some GLSs (glucoalyssin, glucoerucin, glucotropaeolin, glucoraphasatin, and glucobrassicin) increased their concentration in radish sprouts grown in darkness when the presence of MeJA was not higher than $100 \mu \mathrm{M}$ [30].

Light, in addition to being a vital element required for plant survival, constitutes a factor with the capacity to critically influence a range of variations regarding the composition and metabolism observed during sprout growth. In connection to this role, light generates stress in plants and thus, activates specific enzymatic pathways of interest for the production of health-promoting bioactive compounds [25]. In this sense, the wavelength of the spectra applied during the development of seedlings has shown interesting changes. Nowadays, the use of LED lights allows us to apply and characterize the effects on plant growth and composition of all of the spectra, including far-red light (>700 nm). Far-red light has been proven to be a powerful booster that enhances the occurrence of glucosinolates and phenolic compounds in kale sprouts (Figure 1) [32].

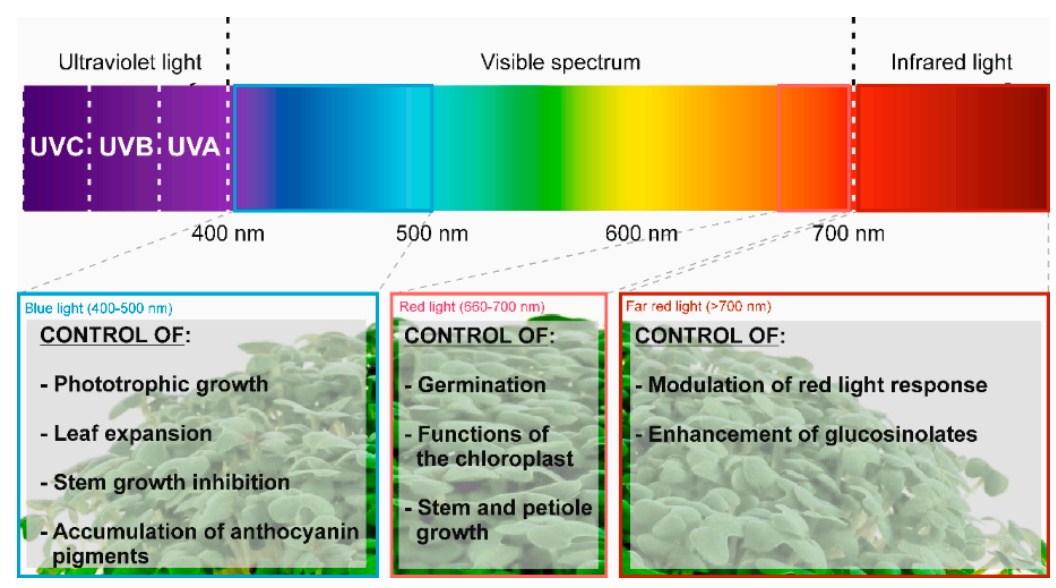

Figure 1. Light spectra influence on the development of kale sprouts.

Carvalho et al. observed that the application of different light wavelengths $(470,660$, and $730 \mathrm{~nm})$ modifies diverse molecular pathways routes in cells, affecting the concentration of bioactive phytochemicals (Table 2), with the most remarkable combination being the use of far-red light with other colors like blue (responsible for the regulation of phenolic compounds) and white, and having the appropriate amount of time in darkness (enhanced the total GLSs by 20.0\%), throwing off interesting results compared to the regular application of white light and darkness (Table 2). 


\section{The Challenges of Including Cruciferous Sprouts in Balanced Diets and Personalized Nutrition}

Balanced diets are critical for the provision of energy and nutrients essential to human health and well-being. Besides, a balanced nutritional supply should be considered carefully in diverse pathophysiological situations. Under a specific physiological status, a given nutrient supply could constitute a preventive or a risk factor. Anyway, to date, a consensus on the most appropriate dietary patterns has been set up, featuring a high proportion of plant foods to lower the incidence and severity of a number of degenerative pathologies, namely cardiovascular diseases, metabolic disturbances, and tumoral processes. This is of special relevance regarding the specific molecules prone to developing biological functions in humans. Indeed, (poly)phenols and GLSs, in addition to bioactive nutrients, are able to produce diverse effects that go beyond basic nutrition, being active on diverse pathophysiological processes and capable of selectively affecting cell proliferation, apoptosis, inflammation, cell differentiation, angiogenesis, DNA repair, and detoxification [36].

Nowadays, it is well accepted that the consumption of cruciferous sprouts is positive for the prevention of health problems, based on the presence of a number of bioactive secondary metabolites (phytochemicals) that naturally occur in plant foods, which have the capacity to act on diverse molecular targets into cells. This range of molecular mechanisms, which is susceptible to activation or inhibition by the GLSs, ITCs, and (poly)phenols present in cruciferous sprouts triggers diverse pathways governed by the expression of a broad variety of genes. Among them, to date, the following pathways have been identified: the inhibition of the DNA binding of carcinogens, the stimulation of detoxification of potentially damaging compounds, DNA repair, the repression of cell proliferation and angiogenesis (directly related to tumor growth and metastasis), the induction of apoptosis of malignant cells $[37,38]$, and the ability to enhance the antioxidant tools of cells and promote free radical scavenging $[39,40]$. Regarding this biological activity, the modulation of the inflammatory cascade, and more specifically, the transcription factor NF-KB by GLSs, ITCs, and (poly)phenols, are also involved in the anticancer activity [41]. Hence, hereafter, the evidence on the value of incorporating cruciferous sprouts to regular diets to prevent a number of clinical situations is reviewed (Table 3), and the molecular mechanisms involved are also discussed.

Table 3. Demonstrated health benefits of cruciferous sprouts under a range of pathophysiological conditions.

\begin{tabular}{|c|c|c|c|c|c|}
\hline Matrix & $\begin{array}{c}\text { Pathophysiological } \\
\text { Condition }\end{array}$ & Effect & Model & Action Mechanism Z & Ref. \\
\hline $\begin{array}{l}\text { Broccoli } \\
\text { sprouts }\end{array}$ & Metabolic profile & $\begin{array}{c}\text { No specific effect } \\
\text { monitored }\end{array}$ & Humans & $\begin{array}{l}\text { FA } 14: 1, \text { FA } 16: 1, \text { FA } 18: 1, \text { FA } 14: 0, \text { FA } \\
\text { 16:0, FA 18:0, } \\
\text { dehydroepiandrosterone, glutathione, } \\
\text { cysteine, and glutamine }(\uparrow) \\
\text { Deoxy-uridin monophosohate }(\downarrow)\end{array}$ & [42] \\
\hline Radish sprouts & Energy metabolism & Decrease glucose level & $\begin{array}{c}\text { Drosophila } \\
\text { melanogaster }\end{array}$ & Expression of spargel $(\uparrow)$ & [43] \\
\hline $\begin{array}{l}\text { Broccoli } \\
\text { sprouts }\end{array}$ & Pregnancy & $\begin{array}{l}\text { Prevention of brain } \\
\text { injury in newborns }\end{array}$ & Rats & Not determined & [44] \\
\hline $\begin{array}{l}\text { Broccoli } \\
\text { sprouts }\end{array}$ & $\begin{array}{l}\text { Inflammation and } \\
\text { oxidative stress }\end{array}$ & $\begin{array}{l}\text { Modulation of } \\
\text { inflammation and } \\
\text { vascular events }\end{array}$ & Humans & Not determined & [45] \\
\hline $\begin{array}{l}\text { Broccoli } \\
\text { sprouts }\end{array}$ & $\begin{array}{l}\text { Inflammation in } \\
\text { overweight } \\
\text { population }\end{array}$ & $\begin{array}{l}\text { Anti-inflammatory } \\
\text { activity }\end{array}$ & Humans & IL-6 and C-reactive protein $(\downarrow)$ & [46] \\
\hline $\begin{array}{l}\text { Broccoli sprout } \\
\text { powder }\end{array}$ & Diabetes & Anti-inflammatory effect & Humans & C-reactive protein $(\downarrow)$ & [47] \\
\hline $\begin{array}{l}\text { Broccoli } \\
\text { sprouts }\end{array}$ & Hypertension & $\begin{array}{c}\text { Does not improve } \\
\text { endothelial function of } \\
\text { hypertension in humans }\end{array}$ & Humans & Not determined & [48] \\
\hline
\end{tabular}


Table 3. Cont

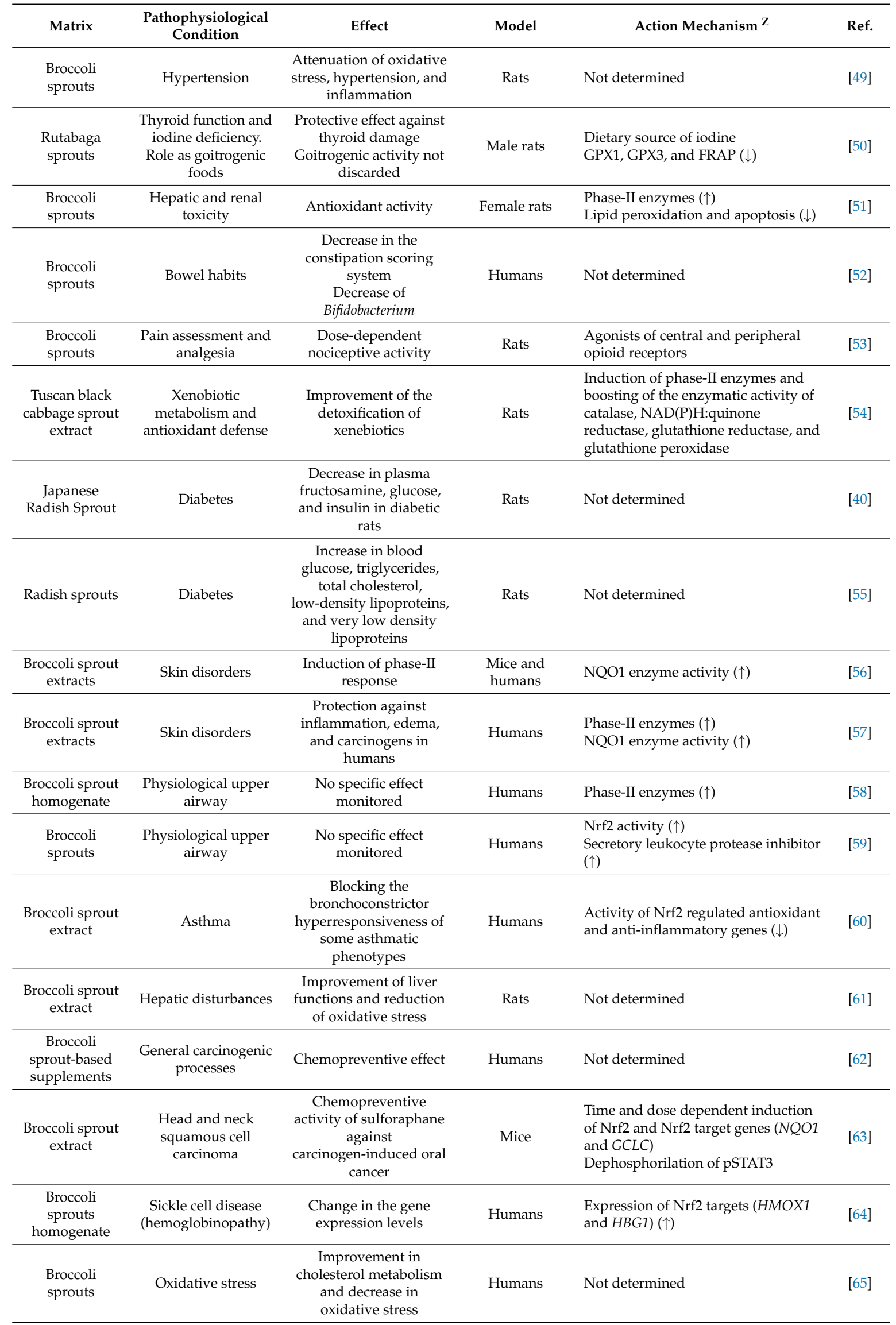


Table 3. Cont.

\begin{tabular}{|c|c|c|c|c|c|}
\hline Matrix & $\begin{array}{l}\text { Pathophysiological } \\
\text { Condition }\end{array}$ & Effect & Model & Action Mechanism $\mathrm{Z}$ & Ref. \\
\hline $\begin{array}{l}\text { Broccoli } \\
\text { sprouts }\end{array}$ & $\begin{array}{l}\text { General carcinogenic } \\
\text { processes }\end{array}$ & Chemopreventive agent & Humans & Histone deacetylase activity $(\downarrow)$ & [66] \\
\hline $\begin{array}{l}\text { Broccoli } \\
\text { sprouts }\end{array}$ & Unspecific frame & Not determined & Humans & Histone deacetylase activity $(\downarrow)$ & [67] \\
\hline $\begin{array}{l}\text { Broccoli } \\
\text { sprouts }\end{array}$ & $\begin{array}{c}\text { Antimicrobial } \\
\text { activity against } \\
\text { Helicobacter pylori }\end{array}$ & $\begin{array}{l}\text { Reduction of Helicobacter } \\
\text { pylori colonization in } \\
\text { mice } \\
\text { Enhancement of } \\
\text { sequelae of Helicobacter } \\
\text { pylori infection in mice } \\
\quad \text { and humans }\end{array}$ & $\begin{array}{l}\text { Mice and } \\
\text { humans }\end{array}$ & Not determined & [68] \\
\hline $\begin{array}{l}\text { Broccoli sprout } \\
\text { extract }\end{array}$ & Allergic response & $\begin{array}{l}\text { Broccoli sprouts reduce } \\
\text { the impact of particulate } \\
\text { pollution of allergic } \\
\text { disease and asthma }\end{array}$ & Humans & Not determined & [69] \\
\hline $\begin{array}{c}\text { Broccoli sprout } \\
\text { extract }\end{array}$ & Prostate cancer & Inconclusive & Humans & Not determined & [70] \\
\hline $\begin{array}{l}\text { Broccoli sprout } \\
\text { and } \\
\text { myrosinase-treated } \\
\text { broccoli sprout } \\
\text { extracts }\end{array}$ & $\begin{array}{l}\text { Chemoprevention of } \\
\text { d carcinogenesis } \\
\text { processes }\end{array}$ & Inconclusive & Humans & $\begin{array}{l}\text { No dose response was observed for } \\
\text { molecular targets }\end{array}$ & [71] \\
\hline $\begin{array}{l}\text { Broccoli sprout } \\
\text { extract }\end{array}$ & Psychiatric disorders & $\begin{array}{l}\text { Improvement of the } \\
\text { cognitive function in } \\
\text { patients affected by } \\
\text { schizophrenia }\end{array}$ & Humans & Not determined & {$[72]$} \\
\hline $\begin{array}{l}\text { Broccoli sprout } \\
\text { extract }\end{array}$ & Type II diabetes & $\begin{array}{l}\text { Reduction of fasting } \\
\text { blood glucose and } \\
\text { glycated hemoglobin }\end{array}$ & Mice & $\begin{array}{l}(\uparrow) \text { Nuclear translocation of Nrf2 } \\
(\downarrow) \text { Glucose production and } \\
\text { intolerance }\end{array}$ & [73] \\
\hline $\begin{array}{l}\text { Broccoli sprout } \\
\text { extract }\end{array}$ & $\begin{array}{l}\text { Neurological } \\
\text { disorder }\end{array}$ & $\begin{array}{l}\text { Inconclusive } \\
\text { improvement of Autism } \\
\text { symptoms }\end{array}$ & Humans & $\begin{array}{l}(\uparrow) \text { Gene transcription in multiple cell } \\
\text { signaling pathways }\end{array}$ & {$[74]$} \\
\hline $\begin{array}{l}\text { Broccoli sprout } \\
\text { homogenate }\end{array}$ & Viral infections & $\begin{array}{l}\text { Enhancement of } \\
\text { antiviral defense } \\
\text { response }\end{array}$ & Humans & $\begin{array}{l}\text { Modulation of natural killer cell } \\
\text { activation } \\
\text { Production of granzyme B by natural } \\
\text { killer cells }(\uparrow)\end{array}$ & [75] \\
\hline \multicolumn{6}{|c|}{$\begin{array}{l}{ }_{Z}^{Z} \text { FA, fatty acids; FRAP, ferric reducing activity of plasma; GCLC, glutamate-cysteine ligase catalytic subunit; GPX1, } \\
\text { cytosolic glutathione peroxidase-1; GPX3, cytosolic glutathione peroxidase-3; HBG1, Hemoglobin subunit gamma } \\
\text { 1; HMOX1, heme oxygenase (decycling) } 1 \text {; IL-6, interleukina } 6 \text {; NAD(P)H, nicotinamide adenine dinucleotide } \\
\text { phosphate; NQO1, NAD(P)H:quinone oxidoreductase } 1 \text {; TNF- } \alpha \text {, tumor necrosis factor-alpha; Nrf2, nuclear factor } \\
\text { erythroid 2-related factor } 2 \text {; pSTAT3, signal transducer and activator of transcription-3; TSH, thyroid stimulating } \\
\text { hormone. }(\downarrow \uparrow) \text { Non-significant variation, }(\downarrow) \text { decrease, and }(\uparrow) \text { increase. }\end{array}$} \\
\hline
\end{tabular}

\subsection{Effect of Cruciferous Sprouts on Type 2 Diabetes Mellitus}

Type 2 diabetes mellitus (DM) is characterized by hyperglycemia and abnormal carbohydrate, lipid, and protein metabolism; it is a multifactorial condition triggered by disturbances of insulin activity in peripheral tissues [76]. In mammals, insulin stimulates the disposal of glucose into skeletal muscle and adipose tissue, while lower levels of gluconeogenesis and glyconeogenesis in hepatocytes suppress the release of free fatty acids from adipose tissue and modulate the transport of amino acids to muscle and liver, reducing protein catabolism [40,77]. Plant foods attenuate the severity of DM by enhancing the sensitivity of cells to insulin due to their content in (poly)phenols [78]. In this regard, dietary intervention with broccoli sprouts in DM patients contributes to the reduction of fasting blood glucose and insulin concentration and resistance to almost physiological levels [4].

The effects on DM of cruciferous sprouts were demonstrated by Taniguchi et al. (2006) using Japanese radish sprouts in normal and streptozotin-induced diabetic rats [40]. The ingestion of radish sprouts lowered the plasma levels of fructosamine and glucose with a decrease in the plasma level of insulin, demonstrating that the hypoglycemia caused by the intake of radish sprouts could be not due to an augment of insulin production but is due to an improved sensitivity or an insulin-like activity [40]. 
Besides, the authors proposed that hypoglycemic activity could be influenced by the radical scavenging activity and thus, the antioxidant potential of the phenolic compounds present in this food. Indeed, the flavonoids improved the insulin sensitivity, allowing a successful hypoglycemic effect $[79,80]$. More recently, Baenas et al. (2016) studied the metabolic activity of radish sprout-derived ITCs in Drosofila melanogaster, demonstrating a decrease in the glucose content in the flies and upregulation of the spargel gene (the homolog of the mammalian PPAR $\gamma$-coactivator $1 \alpha$ ), as well as the inhibition of $\alpha$-amylase and $\alpha$-glucosidase in vitro [43]. Hence, it was proven that the intake of radish sprouts decreases the glucose content in fruit flies by modulating the energy metabolism.

The metabolic disturbances of DM featured also side complications that could be attenuated by the bioactive phytochemicals present in cruciferous sprouts. In this aspect, it has been noticed the occurrence of vascular complications that are closely related to an event known as "metabolic memory" [81], through which the reduction of sugars leads to in the formation of Schiff bases and Amadory products, and the repeated cycles of dehydration and concentration give rise to advanced glycation end products [82]. The slow ratio of metabolism of these products, as well as their capacity to induce the expression of their own receptors fits the concept of "metabolic memory" [83]. The interaction of advanced glycation end products to their receptor elicits the generation of ROS and triggers the inflammatory cascade, as well as thrombotic and fibrotic reactions in a diverse range of cells and tissues [82]. Such vascular effects associated with DM require the development of new therapeutic approaches that contribute to moderating the severity of these processes [81]. So, it has been revealed that the consumption of cruciferous sprouts provides bioavailable ITCs, including SFN and others. In connection with the bioavailability of ITCs, besides other biological actions, it is inhibited the formation of glycation end products [84], thus decreasing the expression and excretion of biomarkers of inflammation (prostaglandins) and thrombosis (thromboxanes) in humans [45]. These findings suggest a possible contribution of dietary sources of ITCs as preventive agents against the micro- and macro-vascular complications of diabetic conditions [81].

Summarizing the relevance of broccoli sprouts to modulate DM in diabetic processes, to the present date, it has been demonstrated that the consumption of these bioactive-rich foods for a relatively short period (4 weeks), results in a significant decrease in circulating insulin in DM patients [85] by a number of molecular mechanisms, promoting cruciferous sprouts as a valuable food for balanced diets.

\subsection{Anti-Inflammatory Activity of Cruciferous Sprouts}

The available information retrieved from basic and epidemiologic research reveals that, nowadays, it is accepted that secondary metabolites of cruciferous foods prevent inflammation through the capacity to activate the Keap1/Nrf2/ARE pathway [86]. In this aspect, the ITCs are efficient blockers of the cascade of molecular events following the actions of pro-inflammatory stimuli on endothelial cells by modulating the expression of chemoattractant and adhesion molecules or by preventing the phosphorylation and degradation of key kinases involved in the inflammatory pathways, among other mechanisms [87]. These biological functions of ITCs further contribute to the modulation of atherosclerotic events and suppress raised wall thickness, structural derangement, vascular fibrosis, inflammation, oxidative/nitrative stress, and apoptosis [81].

Dietary intervention with broccoli sprouts led to a significant decrease in the plasma levels of C-reactive protein [47], which is produced by hepatocytes in response to a variety of inflammatory cytokines [88]. This was further confirmed by López-Chillón et al. (2018) in an interventional follow-up study aimed at monitoring the anti-inflammatory effect of the daily consumption of broccoli sprouts for 70 days in overweight volunteers with chronic subclinical inflammation and augmented levels of IL-6, TNF- $\alpha$, and C-reactive protein [46]. In this intervention, the daily ingestion of $30 \mathrm{~g}$ of broccoli sprouts resulted in a significant decrease in the plasma levels of IL-6 and C-reactive protein by $38.0 \%$ and $59.0 \%$, respectively. The correlation analyses developed by the authors revealed a significant relationship between the decrease of the inflammatory markers and the plasma levels of the bioactive 
sulfur compounds of broccoli sprouts. The authors speculated that the eventual participation of the Keap1/Nrf2/ARE pathway may also be responsible for the monitored effect [46].

Medina et al. (2014) revealed that the intake of broccoli sprouts constitutes a dietary intervention capable of modulating the level of urinary markers of inflammation and vascular events (prostaglandins and thromboxanes), while OS was not modified in healthy volunteers taking 30 or $60 \mathrm{~g}$ of broccoli sprouts [45]. This acute intervention monitored the expression of gold markers by advanced chromatography and spectrometry methods that prompted them to report a decrease in the urinary expression of tetranor-PGEM and $11 \beta-\mathrm{PGF}_{2 \alpha}$, as well as 11 -dehydro-TXB $\mathrm{B}_{2}$. These results reinforce previous data on the effects of ITCs as modulators of inflammatory processes, even as a short or acute intervention [45] but would require longer studies. Despite this evidence, to date, controversy remains concerning the anti-inflammatory activity of ITCs because of the gap in knowledge on the NF-kB-dependent transcriptional activity in endothelial cells exposed to these bioactive compounds [81].

\subsection{Capacity of Bioactive Molecules to Modulate Oxidative Stress (OS)}

Cruciferous sprouts have also been cited as valuable sources of natural antioxidants, namely vitamins $\mathrm{A}, \mathrm{B}_{6}, \mathrm{C}$, and $\mathrm{K}$, as well as lutein, zeaxanthin, other carotenoids, and tocopherols [89]. Additionally, an appreciable role of the antioxidant activity of these food matrices is attributed to flavonoids (flavonols and anthocyanins) and phenolic acids as well as sulfur-based compounds (GLSs and ITCs), according to the extensive literature available [89].

Nuclear factor (eryhroid-derived 2)-like 2 (Nrf2) is a transcription factor that is modulated by ITCs and is responsible for the regulation of the redox balance [4]. In addition, inside the cells, the bioactive ITCs (e.g., SFN) interact with Keap1/Nfr2/ARE pathway [86], preventing the risk of cell malignancy and the onset of cancer processes as a consequence of an increased level of ROS [90,91]. In this regard, it has been observed that ITCs decrease lipid peroxidation by up to $18.0 \%$ after the consumption of broccoli sprouts [92]. An additional demonstration of the capacity of broccoli sprouts to prevent OS was provided by Zhu et al. (2008), who reported that the oral ingestion of broccoli sprouts, as a dietary source of SFN, protected smooth muscle cells from oxidative injury by inducing the cellular and mitochondrial antioxidants and phase-II enzymes (superoxide dismutase, catalase, reduced glutathione, glutathione peroxidase, glutathione reductase, glutathione-S-transferase, and NAD $(\mathrm{PH})$ quinone oxidoreductase 1) [93].

\subsection{Enhancing the Consumption of Cruciferous Sprouts to Reduce Carcinogenesis}

A range of tumor types affects humans, even though medical treatments have experienced an improvement in the last years. In addition, the newly described anti-cancer therapies are not free of toxic effects that impact negatively on the patients' health [94]. The current advances in plant secondary metabolites for anti-cancer activities, which have fewer side effects, either by themselves or as coadjutants of anti-tumor therapies, could turn into more efficient therapies. Thus, plant-derived metabolites are good sources of new active anti-cancer drugs with reduced cytotoxicity [95].

The bioactive secondary metabolites in cruciferous sprouts have been characterized as being capable of reducing the incidence of cancer, according to a range of properties, such as anti-proliferation and apoptotic cell death activity [94]. Many times, the induction of cancer processes is based on exposure to xenobiotics, whose removal could contribute to reducing the carcinogenesis risk. In this regard, Melega et al. (2013) studied the capacity of sprout extract from Tuscan black cabbage to metabolize xenobiotic (phase-I and phase-II) enzymes and antioxidant defenses in vivo and demonstrated its capability to modulate the expression and activity pattern of hepatic phase-I cytochrome P450 monooxygenase while increasing the activity of the cell antioxidant machinery [54]. The authors attributed the plethora of molecular effects observed to eventual additive and/or synergistic interactions between the diverse bioactive nutrients and non-nutrients that impact the 
multiple mechanisms involved in the development and advancement of the multistep carcinogenesis events [54].

The epidemiological evidence available indicates that frequent intake of cruciferous foods is associated with lower incidence of multiple tumor types, due to the capacity of ITCs to interact with the Keap1/Nfr2/ARE pathway [86], contributing to the delay or even the reversal of the development of pre-neoplastic lesions, thereby improving survival rates by acting as 'therapeutic' agents to malignant cells [96].

The ITCs phenethyl isothiocyanate (PEITC), benzyl isothiocyanate (BITC), and SFN, have been demonstrated to have chemo-preventive activity in diverse in vitro models, exhibiting multi-target activities in cells and tissues [41]. Early works of Fahey et al. (1997) demonstrated the capacity of broccoli sprouts to reduce the incidence of breast cancer in vivo due to the presence of ITCs acting as inducers of enzymes that protect against carcinogens. It is worth mentioning that broccoli sprouts contain low amounts of indole GLSs (precursor of indol-3-carbinol), which were related to tumor promotion in experiments designed to test extremely high doses that are not representative of a dietary intake [97].

The potential of bioactive compounds of broccoli sprouts to act as anti-proliferative agents against intestinal tumor processes has been attributed, still in a partial extent, to the metabolism of ITCs by the biological machinery of enterocytes and hepatocytes [98,99]. However, as suggested by Baenas et al., (2015), the anti-tumor contribution of ITCs, together with other bioactive compounds present in broccoli sprouts, requires further study, since the higher activity demonstrated with whole extracts, when compared to isolated SFN, may indicate synergic activities [98,99].

Munday et al. (2008), demonstrated the inhibitory effect of broccoli sprouts on urinary bladder carcinogenesis through an in vivo assay that revealed the capacity of freeze-dried aqueous extract of broccoli sprouts to decrease its incidence, multiplicity, size, and progression, induced by $\mathrm{N}$-butyl- $N$-(4-hydroxybutyl) nitrosamine in rats [100]. Interestingly, this inhibitory activity was associated (and significantly correlated) with a significant induction of glutathione-S-transferase and $\mathrm{NAD}(\mathrm{P}) \mathrm{H}$-quinone oxydoreductase I in the bladder and was related to the presence of bioactive ITCs in broccoli sprouts that, in bladder cells, in vitro and in vivo, induced the expression and activity of glutathione-S-transferase and $\mathrm{NAD}(\mathrm{P}) \mathrm{H}$ :quinone oxidoreductase 1 by up to 3.4 and 2.7-fold, respectively [101]. This evidence further demonstrated the anti-cancer potency of broccoli sprouts, reinforcing previous findings of induced apoptosis and cell cycle arrest in bladder cancer cells, as well as inhibiting angiogenesis, which is associated with tumor progression and metastasis [102-106]. The delivery of ITCs from broccoli sprouts to the bladder during urinary excretion could reduce the incidence of bladder cancer, although the urinary concentration of ITCs capable of developing this protective effect remains to be determined [100].

In another study, Dinkova-Kostova et al. (2010), revealed that feeding mice with broccoli sprouts for 13 weeks with daily doses of $10 \mu \mathrm{mol}$ of GR protected against the development of skin tumors for 13 weeks and reduced the multiplicity and volume of established tumors by $47.0 \%$ and $70.0 \%$, respectively [107]. This finding differs from previous works in terms of the application form of the broccoli sprout extract. In this case, topical application reduced the number of small tumors, but not large tumors, an effect that seemed to be due to the local concentration of the bioactive agent (SFN), as well as the types of derivatives produced as a consequence of the metabolic reaction in diverse cell types and tissues [86]. The authors speculate that feeding mice with broccoli sprouts containing GR protects against skin cancer by unknown mechanisms; however, the available knowledge on the molecular pathways targeted by these compounds suggests that they cause cell cycle arrest and apoptosis and thus, inhibit tumor development. Knatko et al. (2016) demonstrated that the impact of dietary ITCs on the incidence and severity of skin cancer could be related to the protection mediated by the Keap1/Nrf2/ARE pathway applying a mouse model [108]. Recently, a placebo-controlled, randomized clinical trial in which almost 300 volunteers ingested a broccoli sprout-based beverage containing $40 \mathrm{mmol}$ SFN and $600 \mathrm{mmol}$ GR demonstrated that the detoxification of benzene and 
acrolein mercapturic acids was enhanced by the broccoli sprout beverage by $61.0 \%$ and $23.0 \%$, respectively [109]. This result is in agreement with the described capacity of the bioactive compounds in cruciferous sprouts to detoxify environmental carcinogens and toxins.

Once some of the health benefits associated with the consumption of broccoli sprouts had been identified, it was necessary to shed some light on the bioactive compounds responsible for such healthy attributions. In this regard, even though SFN and iberin have been reported as the major ITCs of broccoli sprouts, their functional attributions seem not to be responsible for the biological benefits associated with the consumption of these sprouts. In this aspect, Riedl et al. (2009) performed a placebo-controlled, single blind, dose-escalation trial that included 65 volunteers who ingested from 25 to $200 \mathrm{~g}$ of broccoli sprouts homogenates daily (corresponding to 13-102 mmol SFN), for three days [58]. This assay demonstrated a significant correlation between the dietary intake of this ITC and the induction of phase-II mRNA in the lavage fluid of the upper airways. This consequence was attributed to the modulation of the expression of glutathione-S-transferase Mu-1 (GSTM1), glutathione-S-transferase Pi-1 (GSTP1), NAD(P)H quinone dehydrogenase 1 (NQO1), and HO-1 genes by amounts of broccoli sprouts equal to or higher than $100 \mathrm{~g}$ [58] and supports the development of future clinical studies aiming to examine the potential benefits of SFN in modulating allergic respiratory inflammation caused by oxidative insults.

With respect to the anti-cancer mechanisms of action of isothiocyanates, it has been demonstrated that this follows two main routes: a reversible reaction of the electrophile central carbon with cysteine residues in proteins and glutathione towards the formation of thiocarbamate products and irreversible alkylation reactions with amino-groups in N-terminal residues of proteins with the lysine or secondary amines [110]. However, according to the extensive descriptions available in the literature, the main molecular mechanisms involved in the anti-tumor activity of ITCs are represented by their capacity to inhibit the phase-I enzymes cytochrome P-450s, which are, in turn, responsible for the activation of carcinogens and the induction of phase-II detoxifying enzymes, viz. quinone reductase, UDP-glucuronosyltransferase, and glutathione-S-transferase, through an Nrf2-dependent pathway $[41,86,111-116]$. The antitumor power of ITCs has also been proven to induce cell cycle arrest and malignant cells apoptosis [117], the generation of ROS [118,119], the capacity to regulate the activation of the STAT3, NF-KB, and Nrf2 transcription factors [111,120,121], and to inhibit Mitogen Activated Protein Kinases (MAPK) and PKC activities [119,122]. However, the capacity of (poly)phenols and GLSs to modulate the activity of Nrf2 should be taken cautiously because this has been recently related to certain side effects, such as cancer cells survival, and resistance to chemotherapeutics and radiotherapy [123].

In addition to the described impact of cruciferous bioactives on malignant cells, most phytochemicals in cruciferous sprouts are able to modify the immunological microenvironment in which tumor cells grow. In this regard, dietary intake of brassica foods may contribute to the regulation of the functions of the immune system, providing additional and innovative options for cancer treatment in the near future [94].

The interest in cruciferous sprouts as dietary sources of bioactive molecules is even higher because of their relatively low production cost, which has boosted a broad multidisciplinary research approach involving ethnopharmacology, botany, pharmacognosy, and phytochemistry in the recent years [124]. However, in humans, there is a strong inter-individual variability that affects the protective actions of the dietary sources of GLSs and ITCs. This diversity is mainly due to variations in the individual intestinal microbiota that might be featured by distinct thioglucosidase activity and the existence of polymorphisms of glutathione transferases, which are responsible for the metabolism of ITCs, among other factors [107].

Epigenetics is regulated by a number of processes, including the methylation of DNA, the modification of histones, and by non-coding microRNA that are prone to regulating cellular proliferation and viability [125]. Closely related to the investigation of the capacity of cruciferous sprouts (and whatever other foods) to prevent the development of cancer are a number of epigenetic 
studies. In this regard, it has been demonstrated that malignant cells use these epigenetic traits to control growth and metastasis, while, interestingly, bioactive indoles and sulfur-compounds have been revealed as capable of controlling these effects by acting as powerful modulators of DNA methylation and the molecular modification of histones, thus contributing to the prevention of cancer among other pathologies through hormone and non-hormone-based activities. Hence, in general, it has been demonstrated that ITCs and indoles may contribute to the modulation of gene expression related to the metabolism and excretion of xenobiotics, free radical scavenging machinery, regulation of the cellular cycle and apoptosis, and the response of cells against stress [126]. For instance, inducing the demethylation of the $h T E R T$ control region or by regulating miRNA knockdown, through which augment the apoptosis of malignant [125]. In this regard, SFN has been identified as the most relevant secondary metabolite responsible for such activities, with broccoli sprouts being the main dietary source [127].

\section{Conclusions and Future Directions}

To the present date, a number of studies have encouraged the consumption of cruciferous sprouts as interesting sources of biomolecules with beneficial effects on health, such as anti-cancer, anti-inflammatory, and antioxidant capacities.

In the current literature related to cruciferous sprouts and their health benefits, these foods have been consistently demonstrated as contributors to the normalization of blood glucose levels and the lipid profile, as well as to the maintenance of redox balance in cells and tissues. These functions have a direct effect on the overall health of humans. More specifically, it is doubtless that the bioactive compounds in cruciferous sprouts are beneficial for the treatment of some metabolic disorders, such as DM and its associated vascular complications. In parallel to the control of glycaemia and insulin levels and resistance, these foods have a close connection with the plasma lipid profile that constitutes an additional relevant subject in the promotion of health.

It is also important to highlight that the bioavailable bioactive compounds in sprouts constitute a useful dietary tool for modulating the molecular parameters of specific pathophysiological situations (enhancement of phase II enzymes, modulation of the level of interleukine-6, C-reactive protein, and tumor necrosis factor- $\alpha$, and inhibition of NF- $\mathrm{B}$, among others).

On the other hand, the broad information available suggests that the bioactive phytochemicals present in these vegetables have a prominent role in the control of the incidence and severity of a number of cardiovascular processes, contributing to the fine-tuning of dietary habits and to improving human health through the regulation of molecular routes closely related to the onset of a number of diseases. Thus, the development of a number of experimental procedures and epidemiological studies (not only with sprouts but also with cruciferous foods in general) will increase the capacity to prevent and treat health problems with nutrients and phytochemicals.

There is diverse information about the growing conditions for the production of cruciferous sprouts enriched with bioactive compounds (elicitation) to potentiate the biological functions described.

As a general conclusion, it should be mentioned that caution is required when reporting the biological benefits of cruciferous food intake because of the lack of consistent demonstration of the benefits of incorporating these foods into the dietary habits due to the high inter-individual variability of the parameters monitored as well as to the heterogeneity of the interventions (sampling schedules, doses, sample size, etc.) that do not allow us to outline the effective dosages or concentrations of bioactives that should be recommended to achieve the desirable benefits with cruciferous sprouts to take real advantage of the bioactive (poly)phenols and GLSs present in cruciferous foods.

Author Contributions: R.D.-P., D.A.M., and C.G.-V. designed the structure of the review article. Á.A. and R.D.-P. wrote the review article. D.A.M. and C.G.-V. had primary responsibility for final content. All authors critically revised the article for important intellectual content, and approved the final version. 
Funding: This work was supported by the Spanish Ministry of Economy and Competitiveness of the Spanish Government through Research Projects, AGL2013-46247-P, the Grant for Research Groups of Excellence from the Murcia Regional Agency for Science and Technology (Fundación Séneca), Project 19900/GERM/15 and a Private Contract with INBAUTEK SL enterprise, RDP was funded by a postdoctoral contract "Juan de la Cierva de Incorporación" (\#ICJI-2015-25373) from the Ministry of Economy, Industry and Competitiveness of Spain, and A.A by INBAUTEK SL enterprise.

Conflicts of Interest: The authors declare no conflict of interest.

\section{References}

1. Gan, R.-Y.; Lui, W.-Y.; Wu, K.; Chan, C.-L.; Dai, S.-H.; Sui, Z.-Q.; Corke, H. Bioactive compounds and bioactivities of germinated edible seeds and sprouts: An updated review. Trends Food Sci. Technol. 2017, 59, 1-14. [CrossRef]

2. Moreno, D.A.; Perez-Balibrea, S.; Garcia-Viguera, C. Phytochemical quality and bioactivity of edible sprouts. Nat. Prod. Commun. 2006, 11, 1037-1048.

3. Baenas, N.; Ferreres, F.; García-Viguera, C.; Moreno, D.A. Radish sprouts-Characterization and elicitation of novel varieties rich in anthocyanins. Food Res. Int. 2015, 69, 305-312. [CrossRef]

4. Conzatti, A.; Telles da Silva Fróes, F.C.; Schweigert Perry, I.D.; Guerini de Souza, C. Clinical and molecular evidence of the consumption of broccoli, glucoraphanin and sulforaphane in humans. Nutr. Hosp. 2015, 31, 559-569.

5. Baenas, N.; Gómez-Jodar, I.; Moreno, D.A.; García-Viguera, C.; Periago, P.M. Broccoli and radish sprouts are safe and rich in bioactive phytochemicals. Postharvest Boil. Technol. 2017, 127, 60-67. [CrossRef]

6. Baenas, N.; García-Viguera, C.; Moreno, A.D. Elicitation: A Tool for Enriching the Bioactive Composition of Foods. Molecules 2014, 19, 13541. [CrossRef] [PubMed]

7. Gagné, F. Chapter 6-Oxidative Stress. In Biochemical Ecotoxicology; Gagné, F., Ed.; Academic Press: Oxford, UK, 2014; pp. 103-115. [CrossRef]

8. Wang, C.; Wang, C. Anti-nociceptive and anti-inflammatory actions of sulforaphane in chronic constriction injury-induced neuropathic pain mice. Inflammopharmacology 2016, 25, 99-106. [CrossRef] [PubMed]

9. Li, R.; Zhu, Y. The primary active components, antioxidant properties, and differential metabolite profiles of radish sprouts (Raphanus sativus L.) upon domestic storage: Analysis of nutritional quality. J. Sci. Food Agric. 2018, 98, 5853-5860. [CrossRef]

10. Jeon, J.; Kim, J.K.; Kim, H.; Kim, Y.J.; Park, Y.J.; Kim, S.J.; Kim, C.; Park, S.U. Transcriptome analysis and metabolic profiling of green and red kale (Brassica oleracea var. acephala) seedlings. Food Chem. 2018, 241, 7-13. [CrossRef]

11. Liang, X.; Lee, H.W.; Li, Z.; Lu, Y.; Zou, L.; Ong, C.N. Simultaneous Quantification of 22 Glucosinolates in 12 Brassicaceae Vegetables by Hydrophilic Interaction Chromatography-Tandem Mass Spectrometry. ACS Omega 2018, 3, 15546-15553. [CrossRef]

12. Podsędek, A. Natural antioxidants and antioxidant capacity of Brassica vegetables: A review. LWT-Food Sci. Technol. 2007, 40, 1-11. [CrossRef]

13. De Camargo, C.A.; Schwember, R.A.; Parada, R.; Garcia, S.; Maróstica Júnior, R.M.; Franchin, M.; Regitano-d'Arce, A.M.; Shahidi, F. Opinion on the Hurdles and Potential Health Benefits in Value-Added Use of Plant Food Processing By-Products as Sources of Phenolic Compounds. Int. J. Mol. Sci. 2018, 19, 3498. [CrossRef] [PubMed]

14. Francisco, M.; Moreno, D.A.; Cartea, M.E.; Ferreres, F.; García-Viguera, C.; Velasco, P. Simultaneous identification of glucosinolates and phenolic compounds in a representative collection of vegetable Brassica rapa. J. Chromatogr. A 2009, 1216, 6611-6619. [CrossRef] [PubMed]

15. Ferreres, F.; García-Viguera, C.; Gil-Izquierdo, Á.; Moreno, D.A.; Pérez-Balibrea, S. Acylated anthocyanins in broccoli sprouts. Food Chem. 2010, 123, 358-363.

16. Qian, H.; Liu, T.; Deng, M.; Miao, H.; Cai, C.; Shen, W.; Wang, Q. Effects of light quality on main health-promoting compounds and antioxidant capacity of Chinese kale sprouts. Food Chem. 2016, 196, 1232-1238. [CrossRef] [PubMed]

17. Sandoval-Ramírez, B.A.; Catalán, Ú.; Fernández-Castillejo, S.; Rubió, L.; Macià, A.; Solà, R. Anthocyanin Tissue Bioavailability in Animals: Possible Implications for Human Health. A Systematic Review. J. Agric. Food Chem. 2018, 66, 11531-11543. [CrossRef] [PubMed] 
18. Barba, F.J.; Nikmaram, N.; Roohinejad, S.; Khelfa, A.; Zhu, Z.; Koubaa, M. Bioavailability of Glucosinolates and Their Breakdown Products: Impact of Processing. Front. Nutr. 2016, 3, 24. [CrossRef]

19. Wagner, A.; Maria Terschluesen, A.; Rimbach, G. Health Promoting Effects of Brassica-Derived Phytochemicals: From Chemopreventive and Anti-Inflammatory Activities to Epigenetic Regulation. Oxid. Med. Cell. Longev. 2013, 2013, 964539. [CrossRef]

20. Xu, Y.; Szép, S.; Lu, Z. The antioxidant role of thiocyanate in the pathogenesis of cystic fibrosis and other inflammation-related diseases. Proc. Natl. Acad. Sci. USA 2009, 106, 20515-20519. [CrossRef]

21. Hayes, J.D.; Kelleher, M.O.; Eggleston, I.M. The cancer chemopreventive actions of phytochemicals derived from glucosinolates. Eur. J. Nutr. 2008, 47, 73-88. [CrossRef]

22. Sita, G.; Hrelia, P.; Graziosi, A.; Morroni, F. Sulforaphane from Cruciferous Vegetables: Recent Advances to Improve Glioblastoma Treatment. Nutrients 2018, 10, 1755. [CrossRef] [PubMed]

23. Bhandari, R.S.; Jo, S.J.; Lee, G.J. Comparison of Glucosinolate Profiles in Different Tissues of Nine Brassica Crops. Molecules 2015, 20, 15827-15841. [CrossRef] [PubMed]

24. Adwas, A.A.; Elkhoely, A.A.; Kabel, A.M.; Abdel-Rahman, M.N.; Eissa, A.A. Anti-cancer and cardioprotective effects of indol-3-carbinol in doxorubicin-treated mice. J. Infect. Chemother. 2016, 22, 36-43. [CrossRef]

25. Frede, K.; Schreiner, M.; Zrenner, R.; Graefe, J.; Baldermann, S. Carotenoid biosynthesis of pak choi (Brassica rapa ssp. chinensis) sprouts grown under different light-emitting diodes during the diurnal course. Photochem. Photobiol. Sci. 2018, 17, 1289-1300. [CrossRef] [PubMed]

26. Baenas, N.; Villaño, D.; García-Viguera, C.; Moreno, D.A. Optimizing elicitation and seed priming to enrich broccoli and radish sprouts in glucosinolates. Food Chem. 2016, 204, 314-319. [CrossRef]

27. Przybysz, A.; Wrochna, M.; Małecka-Przybysz, M.; Gawrońska, H.; Gawroński, S.W. The effects of Mg enrichment of vegetable sprouts on Mg concentration, yield and ROS generation. J. Sci. Food Agric. 2016, 96, 3469-3476. [CrossRef]

28. Guo, R.; Yuan, G.; Wang, Q. Sucrose enhances the accumulation of anthocyanins and glucosinolates in broccoli sprouts. Food Chem. 2011, 129, 1080-1087. [CrossRef] [PubMed]

29. Pérez-Balibrea, S.; Moreno, D.A.; García-Viguera, C. Improving the phytochemical composition of broccoli sprouts by elicitation. Food Chem. 2011, 129, 35-44. [CrossRef]

30. Al-Dhabi, N.A.; Arasu, M.V.; Kim, S.J.; RomijUddin, M.; Park, W.T.; Lee, S.Y.; Park, S.U. Methyl Jasmonateand Light-Induced Glucosinolate and Anthocyanin Biosynthesis in Radish Seedlings. Nat. Prod. Commun. 2015, 10, 1211-1214.

31. Yuan, G.; Wang, X.; Guo, R.; Wang, Q. Effect of salt stress on phenolic compounds, glucosinolates, myrosinase and antioxidant activity in radish sprouts. Food Chem. 2010, 121, 1014-1019. [CrossRef]

32. Carvalho, S.D.; Folta, K.M. Sequential light programs shape kale (Brassica napus) sprout appearance and alter metabolic and nutrient content. Hortic. Res. 2014, 1, 8. [CrossRef] [PubMed]

33. Wei, J.; Miao, H.; Wang, Q. Effect of glucose on glucosinolates, antioxidants and metabolic enzymes in Brassica sprouts. Sci. Hortic. 2011, 129, 535-540. [CrossRef]

34. Baenas, N.; García-Viguera, C.; Moreno, D.A. Biotic Elicitors Effectively Increase the Glucosinolates Content in Brassicaceae Sprouts. J. Agric. Food Chem. 2014, 62, 1881-1889. [CrossRef]

35. Park, W.T.; Kim, Y.B.; Seo, J.M.; Kim, S.-J.; Chung, E.; Lee, J.-H.; Park, S.U. Accumulation of Anthocyanin and Associated Gene Expression in Radish Sprouts Exposed to Light and Methyl Jasmonate. J. Agric. Food Chem. 2013, 61, 4127-4132. [CrossRef] [PubMed]

36. Guo, R.; Yuan, G.; Wang, Q. Effect of sucrose and mannitol on the accumulation of health-promoting compounds and the activity of metabolic enzymes in broccoli sprouts. Sci. Hortic. 2011, 128, 159-165. [CrossRef]

37. Gupta, S.C.; Kim, J.H.; Prasad, S.; Aggarwal, B.B. Regulation of survival, proliferation, invasion, angiogenesis, and metastasis of tumor cells through modulation of inflammatory pathways by nutraceuticals. Cancer Metastasis Rev. 2010, 29, 405-434. [CrossRef]

38. Surh, Y.J. Cancer chemoprevention with dietary phytochemicals. Nat. Rev. Cancer 2003, 3, 768-780. [CrossRef]

39. Banihani, S.A. Radish (Raphanus sativus) and Diabetes. Nutrients 2017, 9, 1014. [CrossRef]

40. Taniguchi, H.; Kobayashi-Hattori, K.; Tenmyo, C.; Kamei, T.; Uda, Y.; Sugita-Konishi, Y.; Oishi, Y.; Takita, T. Effect of Japanese radish (Raphanus sativus) sprout (Kaiware-daikon) on carbohydrate and lipid metabolisms in normal and streptozotocin-induced diabetic rats. Phytother. Res. 2006, 20, 274-278. [CrossRef] 
41. Rescigno, T.; Tecce, M.F.; Capasso, A. Protective and restorative effects of nutrients and phytochemicals. Open Biochem. J. 2018, 12, 46-64. [CrossRef]

42. Housley, L.; Magana, A.A.; Hsu, A.; Beaver, L.M.; Wong, C.P.; Stevens, J.F.; Choi, J.; Jiang, Y.; Bella, D.; Williams, D.E.; et al. Untargeted Metabolomic Screen Reveals Changes in Human Plasma Metabolite Profiles Following Consumption of Fresh Broccoli Sprouts. Mol. Nutr. Food Res. 2018, 62, 1700665. [CrossRef] [PubMed]

43. Baenas, N.; Piegholdt, S.; Schloesser, A.; Moreno, D.A.; García-Viguera, C.; Rimbach, G.; Wagner, A.E. Metabolic Activity of Radish Sprouts Derived Isothiocyanates in Drosophila melanogaster. Int. J. Mol. Sci. 2016, 17, 251. [CrossRef] [PubMed]

44. Black, A.M.; Armstrong, E.A.; Scott, O.; Juurlink, B.J.H.; Yager, J.Y. Broccoli sprout supplementation during pregnancy prevents brain injury in the newborn rat following placental insufficiency. Behav. Brain Res. 2015, 291, 289-298. [CrossRef] [PubMed]

45. Medina, S.; Domínguez-Perles, R.; Moreno, D.A.; García-Viguera, C.; Ferreres, F.; Gil, J.I.; Gil-Izquierdo, Á. The intake of broccoli sprouts modulates the inflammatory and vascular prostanoids but not the oxidative stress-related isoprostanes in healthy humans. Food Chem. 2015, 173, 1187-1194. [CrossRef] [PubMed]

46. Lopez-Chillon, M.T.; Carazo-Diaz, C.; Prieto-Merino, D.; Zafrilla, P.; Moreno, D.A.; Villano, D. Effects of long-term consumption of broccoli sprouts on inflammatory markers in overweight subjects. Clin. Nutr. 2018. [CrossRef] [PubMed]

47. Mirmiran, P.; Bahadoran, Z.; Hosseinpanah, F.; Keyzad, A.; Azizi, F. Effects of broccoli sprout with high sulforaphane concentration on inflammatory markers in type 2 diabetic patients: A randomized double-blind placebo-controlled clinical trial. J. Funct. Foods 2012, 4, 837-841. [CrossRef]

48. Christiansen, B.; Bellostas Muguerza, N.; Petersen, A.M.; Kveiborg, B.; Madsen, C.R.; Thomas, H.; Ihlemann, N.; Sorensen, J.C.; Kober, L.; Sorensen, H.; et al. Ingestion of broccoli sprouts does not improve endothelial function in humans with hypertension. PLoS ONE 2010, 5, e12461. [CrossRef] [PubMed]

49. Wu, L.; Noyan Ashraf, M.H.; Facci, M.; Wang, R.; Paterson, P.G.; Ferrie, A.; Juurlink, B.H.J. Dietary approach to attenuate oxidative stress, hypertension, and inflammation in the cardiovascular system. Proc. Natl. Acad. Sci. USA 2004, 101, 7094-7099. [CrossRef] [PubMed]

50. Paśko, P.; Okoń, K.; Krośniak, M.; Prochownik, E.; Żmudzki, P.; Kryczyk-Kozioł, J.; Zagrodzki, P. Interaction between iodine and glucosinolates in rutabaga sprouts and selected biomarkers of thyroid function in male rats. J. Trace Elem. Med. Boil. 2018, 46, 110-116. [CrossRef]

51. Sharma, D.; Sangha, G.K. Antioxidative effects of aqueous extract of broccoli sprouts against Triazophos induced hepatic and renal toxicity in female Wistar rats. J. Appl. Biomed. 2018, 16, 100-110. [CrossRef]

52. Yanaka, A. Daily intake of broccoli sprouts normalizes bowel habits in human healthy subjects. J. Clin. Biochem. Nutr. 2018, 62, 75-82. [CrossRef] [PubMed]

53. Baenas, N.; Gonzalez-Trujano, M.E.; Guadarrama-Enriquez, O.; Pellicer, F.; Garcia-Viguera, C.; Moreno, D.A. Broccoli sprouts in analgesia-Preclinical in vivo studies. Food Funct. 2017, 8, 167-176. [CrossRef] [PubMed]

54. Melega, S.; Canistro, D.; Pagnotta, E.; Iori, R.; Sapone, A.; Paolini, M. Effect of sprout extract from Tuscan black cabbage on xenobiotic-metabolizing and antioxidant enzymes in rat liver. Mutat. Res. Genet. Toxicol. Environ. Mutagen. 2013, 751, 45-51. [CrossRef] [PubMed]

55. Aly, A.A.T.; Fayed, S.A.; Ahmed, A.M.; El Rahim, E.A. Effect of Egyptian Radish and Clover Sprouts on Blood Sugar and Lipid Metabolisms in Diabetic Rats. Glob. J. Biotechnol. Biochem. 2015, 10, 16-21.

56. Dinkova-Kostova, A.T.; Fahey, J.W.; Wade, K.L.; Jenkins, S.N.; Shapiro, T.A.; Fuchs, E.J.; Kerns, M.L.; Talalay, P. Induction of the phase 2 response in mouse and human skin by sulforaphane-containing broccoli sprout extracts. Cancer Epidemiol. Biomark. Prev. 2007, 16, 847-851. [CrossRef] [PubMed]

57. Talalay, P.; Fahey, J.W.; Healy, Z.R.; Wehage, S.L.; Benedict, A.L.; Min, C.; Dinkova-Kostova, A.T. Sulforaphane mobilizes cellular defenses that protect skin against damage by UV radiation. Proc. Natl. Acad. Sci. USA 2007, 104, 17500-17505. [CrossRef]

58. Riedl, M.A.; Saxon, A.; Diaz-Sanchez, D. Oral sulforaphane increases Phase II antioxidant enzymes in the human upper airway. Clin. Immunol. 2009, 130, 244-251. [CrossRef]

59. Meyer, M.; Kesic, M.J.; Clarke, J.; Ho, E.; Simmen, R.C.; Diaz-Sanchez, D.; Noah, T.L.; Jaspers, I. Sulforaphane induces SLPI secretion in the nasal mucosa. Respir. Med. 2013, 107, 472-475. [CrossRef]

60. Brown, R.H.; Reynolds, C.; Brooker, A.; Talalay, P.; Fahey, J.W. Sulforaphane improves the bronchoprotective response in asthmatics through Nrf2-mediated gene pathways. Respir. Res. 2015, 16, 106. [CrossRef] 
61. Kikuchi, M.; Ushida, Y.; Shiozawa, H.; Umeda, R.; Tsuruya, K.; Aoki, Y.; Suganuma, H.; Nishizaki, Y. Sulforaphane-rich broccoli sprout extract improves hepatic abnormalities in male subjects. World J. Gastroenterol. 2015, 21, 12457-12467. [CrossRef]

62. Ushida, Y.S.; Suganuma, H.; Yanaka, A. Low-Dose of the Sulforaphane Precursor Glucoraphanin as a Dietary Supplement Induces Chemoprotective Enzymes in Humans. Food Nutr. Sci. 2015, 6, 1603-1612. [CrossRef]

63. Bauman, J.E.; Zang, Y.; Sen, M.; Li, C.; Wang, L.; Egner, P.A.; Fahey, J.W.; Normolle, D.P.; Grandis, J.R.; Kensler, T.W.; et al. Prevention of Carcinogen-Induced Oral Cancer by Sulforaphane. Cancer Prev. Res. 2016, 9,547-557. [CrossRef]

64. Doss, J.F.; Jonassaint, J.C.; Garrett, M.E.; Ashley-Koch, A.E.; Telen, M.J.; Chi, J.T. Phase 1 Study of a Sulforaphane-Containing Broccoli Sprout Homogenate for Sickle Cell Disease. PLoS ONE 2016, 11, e0152895. [CrossRef] [PubMed]

65. Murashima, M.; Watanabe, S.; Zhuo, X.G.; Uehara, M.; Kurashige, A. Phase 1 study of multiple biomarkers for metabolism and oxidative stress after one-week intake of broccoli sprouts. Biofactors 2004, 22, 271-275. [CrossRef] [PubMed]

66. Myzak, M.C.; Tong, P.; Dashwood, W.M.; Dashwood, R.H.; Ho, E. Sulforaphane retards the growth of human PC-3 xenografts and inhibits HDAC activity in human subjects. Exp. Biol. Med. 2007, 232, 227-234.

67. Clarke, J.D.; Riedl, K.; Bella, D.; Schwartz, S.J.; Stevens, J.F.; Ho, E. Comparison of isothiocyanate metabolite levels and histone deacetylase activity in human subjects consuming broccoli sprouts or broccoli supplement. J. Agric. Food Chem. 2011, 59, 10955-10963. [CrossRef] [PubMed]

68. Yanaka, A.; Fahey, J.W.; Fukumoto, A.; Nakayama, M.; Inoue, S.; Zhang, S.; Tauchi, M.; Suzuki, H.; Hyodo, I.; Yamamoto, M. Dietary sulforaphane-rich broccoli sprouts reduce colonization and attenuate gastritis in Helicobacter pylori-infected mice and humans. Cancer Prev. Res. 2009, 2, 353-360. [CrossRef]

69. Heber, D.; Li, Z.; Garcia-Lloret, M.; Wong, A.M.; Lee, T.Y.; Thames, G.; Krak, M.; Zhang, Y.; Nel, A. Sulforaphane-rich broccoli sprout extract attenuates nasal allergic response to diesel exhaust particles. Food Funct. 2014, 5, 35-41. [CrossRef]

70. Alumkal, J.J.; Slottke, R.; Schwartzman, J.; Cherala, G.; Munar, M.; Graff, J.N.; Beer, T.M.; Ryan, C.W.; Koop, D.R.; Gibbs, A.; et al. A phase II study of sulforaphane-rich broccoli sprout extracts in men with recurrent prostate cancer. Investig. New Drugs 2015, 33, 480-489. [CrossRef]

71. Atwell, L.L.; Zhang, Z.; Mori, M.; Farris, P.; Vetto, J.T.; Naik, A.M.; Oh, K.Y.; Thuillier, P.; Ho, E.; Shannon, J. Sulforaphane Bioavailability and Chemopreventive Activity in Women Scheduled for Breast Biopsy. Cancer Prev. Res. 2015, 8, 1184-1191. [CrossRef]

72. Shiina, A.; Kanahara, N.; Sasaki, T.; Oda, Y.; Hashimoto, T.; Hasegawa, T.; Yoshida, T.; Iyo, M.; Hashimoto, K. An Open Study of Sulforaphane-rich Broccoli Sprout Extract in Patients with Schizophrenia. Clin. Psychopharmacol. Neurosci. 2015, 13, 62-67. [CrossRef] [PubMed]

73. Axelsson, A.S.; Tubbs, E.; Mecham, B.; Chacko, S.; Nenonen, H.A.; Tang, Y.; Fahey, J.W.; Derry, J.M.J.; Wollheim, C.B.; Wierup, N.; et al. Sulforaphane reduces hepatic glucose production and improves glucose control in patients with type 2 diabetes. Sci. Transl. Med. 2017, 9, eaah4477. [CrossRef] [PubMed]

74. Singh, K.; Connors, S.L.; Macklin, E.A.; Smith, K.D.; Fahey, J.W.; Talalay, P.; Zimmerman, A.W. Sulforaphane treatment of autism spectrum disorder (ASD). Proc. Natl. Acad. Sci. USA 2014, 111, 15550-15555. [CrossRef] [PubMed]

75. Muller, L.; Meyer, M.; Bauer, R.N.; Zhou, H.; Zhang, H.; Jones, S.; Robinette, C.; Noah, T.L.; Jaspers, I. Effect of Broccoli Sprouts and Live Attenuated Influenza Virus on Peripheral Blood Natural Killer Cells: A Randomized, Double-Blind Study. PLoS ONE 2016, 11, e0147742. [CrossRef] [PubMed]

76. Musselman, D.L.; Betan, E.; Larsen, H.; Phillips, L.S. Relationship of depression to diabetes types 1 and 2: Epidemiology, biology, and treatment. Biol. Psychiatry 2003, 54, 317-329. [CrossRef]

77. Bessesen, D.H. The role of carbohydrates in insulin resistance. J. Nutr. 2001, 131, 2782s-2786s. [CrossRef] [PubMed]

78. Zaklos-Szyda, M.; Majewska, I.; Redzynia, M.; Koziolkiewicz, M. Antidiabetic effect of polyphenolic extracts from selected edible plants as alpha-amylase, alpha -glucosidase and PTP1B inhibitors, and beta pancreatic cells cytoprotective agents-A comparative study. Curr. Top. Med. Chem. 2015, 15, 2431-2444. [CrossRef]

79. Amer, M.; El-Habibi el, S.; El-Gendy, A. Effects of Trifolium alexandrinum extracts on streptozotocin-induced diabetes in male rats. Ann. Nutr. Metab. 2004, 48, 343-347. [CrossRef] 
80. Wu, L.Y.; Juan, C.C.; Ho, L.T.; Hsu, Y.P.; Hwang, L.S. Effect of green tea supplementation on insulin sensitivity in Sprague-Dawley rats. J. Agric. Food Chem. 2004, 52, 643-648. [CrossRef]

81. Yamagishi, S.I.; Matsui, T. Protective role of sulphoraphane against vascular complications in diabetes. Pharm. Boil. 2016, 54, 2329-2339. [CrossRef]

82. Sourris, K.C.; Forbes, J.M. Interactions between advanced glycation end-products (AGE) and their receptors in the development and progression of diabetic nephropathy-Are these receptors valid therapeutic targets. Curr. Drug Targets 2009, 10, 42-50. [CrossRef] [PubMed]

83. Yamagishi, S.; Matsui, T. Soluble form of a receptor for advanced glycation end products (sRAGE) as a biomarker. Front. Biosci. 2010, 2, 1184-1195. [CrossRef]

84. Maeda, S.; Matsui, T.; Ojima, A.; Takeuchi, M.; Yamagishi, S. Sulforaphane inhibits advanced glycation end product-induced pericyte damage by reducing expression of receptor for advanced glycation end products. Nutr. Res. 2014, 34, 807-813. [CrossRef] [PubMed]

85. Bahadoran, Z.; Tohidi, M.; Nazeri, P.; Mehran, M.; Azizi, F.; Mirmiran, P. Effect of broccoli sprouts on insulin resistance in type 2 diabetic patients: A randomized double-blind clinical trial. Int. J. Food Sci. Nutr. 2012, 63, 767-771. [CrossRef] [PubMed]

86. Dinkova-Kostova, A.T.; Jenkins, S.N.; Fahey, J.W.; Ye, L.; Wehage, S.L.; Liby, K.T.; Stephenson, K.K.; Wade, K.L.; Talalay, P. Protection against UV-light-induced skin carcinogenesis in SKH-1 high-risk mice by sulforaphane-containing broccoli sprout extracts. Cancer Lett. 2006, 240, 243-252. [CrossRef] [PubMed]

87. Chen, X.L.; Dodd, G.; Kunsch, C. Sulforaphane inhibits TNF-alpha-induced activation of p38 MAP kinase and VCAM-1 and MCP-1 expression in endothelial cells. Inflamm. Res. 2009, 58, 513-521. [CrossRef] [PubMed]

88. Du Clos, T.W. Function of C-reactive protein. Ann. Med. 2000, 32, 274-278. [CrossRef] [PubMed]

89. Francisco, M.T.; Tortosa, M.; Martínez-Ballesta, M.C.; Velasco, P.; García-Viguera, C.; Moreno, D.A. Nutritional and phytochemical value of Brassica crops from the agri-food perspective. Anal. Appl. Boil. 2016, 170, 273-285. [CrossRef]

90. Turpaev, K.T. Keap1-Nrf2 signaling pathway: Mechanisms of regulation and role in protection of cells against toxicity caused by xenobiotics and electrophiles. Biochemistry 2013, 78, 111-126. [CrossRef]

91. Vomhof-Dekrey, E.E.; Picklo, M.J., Sr. The Nrf2-antioxidant response element pathway: A target for regulating energy metabolism. J. Nutr. Biochem. 2012, 23, 1201-1206. [CrossRef]

92. Bahadoran, Z.; Mirmiran, P.; Hosseinpanah, F.; Hedayati, M.; Hosseinpour-Niazi, S.; Azizi, F. Broccoli sprouts reduce oxidative stress in type 2 diabetes: A randomized double-blind clinical trial. Eur. J. Clin. Nutr. 2011, 65, 972-977. [CrossRef] [PubMed]

93. Zhu, H.; Jia, Z.; Strobl, J.S.; Ehrich, M.; Misra, H.P.; Li, Y. Potent induction of total cellular and mitochondrial antioxidants and phase 2 enzymes by cruciferous sulforaphane in rat aortic smooth muscle cells: Cytoprotection against oxidative and electrophilic stress. Cardiovasc. Toxicol. 2008, 8, 115-125. [CrossRef] [PubMed]

94. Shin, S.A.; Moon, S.Y.; Kim, W.Y.; Paek, S.M.; Park, H.H.; Lee, C.S. Structure-Based Classification and Anti-Cancer Effects of Plant Metabolites. Int. J. Mol. Sci. 2018, 19, 2651. [CrossRef] [PubMed]

95. Ijaz, S.; Akhtar, N.; Khan, M.S.; Hameed, A.; Irfan, M.; Arshad, M.A.; Ali, S.; Asrar, M. Plant derived anticancer agents: A green approach towards skin cancers. Biomed. Pharm. 2018, 103, 1643-1651. [CrossRef] [PubMed]

96. Lam, T.K.; Gallicchio, L.; Lindsley, K.; Shiels, M.; Hammond, E.; Tao, X.G.; Chen, L.; Robinson, K.A.; Caulfield, L.E.; Herman, J.G.; et al. Cruciferous vegetable consumption and lung cancer risk: A systematic review. Cancer Epidemiol. Biomark. Prev. 2009, 18, 184-195. [CrossRef] [PubMed]

97. Oganesian, A.; Hendricks, J.D.; Pereira, C.B.; Orner, G.A.; Bailey, G.S.; Williams, D.E. Potency of dietary indole-3-carbinol as a promoter of aflatoxin B1-initiated hepatocarcinogenesis: Results from a 9000 animal tumor study. Carcinogenesis 1999, 20, 453-458. [CrossRef]

98. Baenas, N.; Silván, J.M.; Medina, S.; de Pascual-Teresa, S.; García-Viguera, C.; Moreno, D.A. Metabolism and antiproliferative effects of sulforaphane and broccoli sprouts in human intestinal (Caco-2) and hepatic (HepG2) cells. Phytochem. Rev. 2015, 14, 1035-1044. [CrossRef]

99. Kushad, M.M.; Brown, A.F.; Kurilich, A.C.; Juvik, J.A.; Klein, B.P.; Wallig, M.A.; Jeffery, E.H. Variation of glucosinolates in vegetable crops of Brassica oleracea. J. Agric. Food Chem. 1999, 47, 1541-1548. [CrossRef] 
100. Munday, R.; Mhawech-Fauceglia, P.; Munday, C.M.; Paonessa, J.D.; Tang, L.; Munday, J.S.; Lister, C.; Wilson, P.; Fahey, J.W.; Davis, W.; et al. Inhibition of urinary bladder carcinogenesis by broccoli sprouts. Cancer Res. 2008, 68, 1593-1600. [CrossRef]

101. Zhang, Y.; Munday, R.; Jobson, H.E.; Munday, C.M.; Lister, C.; Wilson, P.; Fahey, J.W.; Mhawech-Fauceglia, P. Induction of GST and NQO1 in cultured bladder cells and in the urinary bladders of rats by an extract of broccoli (Brassica oleracea italica) sprouts. J. Agric. Food Chem. 2006, 54, 9370-9376. [CrossRef]

102. Bertl, E.; Bartsch, H.; Gerhauser, C. Inhibition of angiogenesis and endothelial cell functions are novel sulforaphane-mediated mechanisms in chemoprevention. Mol. Cancer 2006, 5, 575-585. [CrossRef] [PubMed]

103. Jackson, S.J.; Singletary, K.W.; Venema, R.C. Sulforaphane suppresses angiogenesis and disrupts endothelial mitotic progression and microtubule polymerization. Vasc. Pharm. 2007, 46, 77-84. [CrossRef] [PubMed]

104. Tang, L.; Zhang, Y. Mitochondria are the primary target in isothiocyanate-induced apoptosis in human bladder cancer cells. Mol. Cancer 2005, 4, 1250-1259. [CrossRef] [PubMed]

105. Tang, L.; Zhang, Y.; Jobson, H.E.; Li, J.; Stephenson, K.K.; Wade, K.L.; Fahey, J.W. Potent activation of mitochondria-mediated apoptosis and arrest in $\mathrm{S}$ and $\mathrm{M}$ phases of cancer cells by a broccoli sprout extract. Mol. Cancer 2006, 5, 935-944. [CrossRef] [PubMed]

106. Thejass, P.; Kuttan, G. Antimetastatic activity of Sulforaphane. Life Sci. 2006, 78, 3043-3050. [CrossRef] [PubMed]

107. Dinkova-Kostova, A.T.; Fahey, J.W.; Benedict, A.L.; Jenkins, S.N.; Ye, L.; Wehage, S.L.; Talalay, P. Dietary glucoraphanin-rich broccoli sprout extracts protect against UV radiation-induced skin carcinogenesis in SKH-1 hairless mice. Photochem. Photobiol. Sci. 2010, 9, 597-600. [CrossRef] [PubMed]

108. Knatko, E.V.; Higgins, M.; Fahey, J.W.; Dinkova-Kostova, A.T. Loss of Nrf2 abrogates the protective effect of Keap1 downregulation in a preclinical model of cutaneous squamous cell carcinoma. Sci. Rep. 2016, 6, 25804. [CrossRef]

109. Chen, W.; Jiang, T.; Wang, H.; Tao, S.; Lau, A.; Fang, D.; Zhang, D.D. Does Nrf2 contribute to p53-mediated control of cell survival and death? Antioxid. Redox Signal. 2012, 17, 1670-1675. [CrossRef]

110. Nakamura, T.; Kawai, Y.; Kitamoto, N.; Osawa, T.; Kato, Y. Covalent modification of lysine residues by allyl isothiocyanate in physiological conditions: Plausible transformation of isothiocyanate from thiol to amine. Chem. Res. Toxicol. 2009, 22, 536-542. [CrossRef]

111. Cheung, K.L.; Kong, A.N. Molecular targets of dietary phenethyl isothiocyanate and sulforaphane for cancer chemoprevention. AAPS J. 2010, 12, 87-97. [CrossRef]

112. Hong, F.; Freeman, M.L.; Liebler, D.C. Identification of sensor cysteines in human Keap1 modified by the cancer chemopreventive agent sulforaphane. Chem. Res. Toxicol. 2005, 18, 1917-1926. [CrossRef] [PubMed]

113. Itoh, K.; Wakabayashi, N.; Katoh, Y.; Ishii, T.; Igarashi, K.; Engel, J.D.; Yamamoto, M. Keap1 represses nuclear activation of antioxidant responsive elements by Nrf2 through binding to the amino-terminal Neh2 domain. Genes Dev. 1999, 13, 76-86. [CrossRef] [PubMed]

114. Juge, N.; Mithen, R.F.; Traka, M. Molecular basis for chemoprevention by sulforaphane: A comprehensive review. Cell. Mol. Life Sci. 2007, 64, 1105-1127. [CrossRef] [PubMed]

115. McMahon, M.; Thomas, N.; Itoh, K.; Yamamoto, M.; Hayes, J.D. Dimerization of substrate adaptors can facilitate cullin-mediated ubiquitylation of proteins by a "tethering" mechanism: A two-site interaction model for the Nrf2-Keap1 complex. J. Biol. Chem. 2006, 281, 24756-24768. [CrossRef] [PubMed]

116. Wu, X.; Zhou, Q.H.; Xu, K. Are isothiocyanates potential anti-cancer drugs? Acta Pharm. Sin. 2009, 30, 501-512. [CrossRef] [PubMed]

117. Lee, J.W.; Cho, M.K. Phenethyl isothiocyanate induced apoptosis via down regulation of Bcl-2/XIAP and triggering of the mitochondrial pathway in MCF-7 cells. Arch. Pharm. Res. 2008, 31, 1604-1612. [CrossRef] [PubMed]

118. Xiao, D.; Powolny, A.A.; Singh, S.V. Benzyl isothiocyanate targets mitochondrial respiratory chain to trigger reactive oxygen species-dependent apoptosis in human breast cancer cells. J. Biol. Chem. 2008, 283, 30151-30163. [CrossRef]

119. Sahu, R.P.; Zhang, R.; Batra, S.; Shi, Y.; Srivastava, S.K. Benzyl isothiocyanate-mediated generation of reactive oxygen species causes cell cycle arrest and induces apoptosis via activation of MAPK in human pancreatic cancer cells. Carcinogenesis 2009, 30, 1744-1753. [CrossRef]

120. Gong, A.; He, M.; Krishna Vanaja, D.; Yin, P.; Karnes, R.J.; Young, C.Y. Phenethyl isothiocyanate inhibits STAT3 activation in prostate cancer cells. Mol. Nutr. Food Res. 2009, 53, 878-886. [CrossRef] 
121. Prawan, A.; Saw, C.L.; Khor, T.O.; Keum, Y.S.; Yu, S.; Hu, L.; Kong, A.N. Anti-NF-kappaB and anti-inflammatory activities of synthetic isothiocyanates: Effect of chemical structures and cellular signaling. Chem. Biol. Interact. 2009, 179, 202-211. [CrossRef]

122. Mukherjee, S.; Dey, S.; Bhattacharya, R.K.; Roy, M. Isothiocyanates sensitize the effect of chemotherapeutic drugs via modulation of protein kinase $C$ and telomerase in cervical cancer cells. Mol. Cell. Biochem. 2009, 330, 9-22. [CrossRef] [PubMed]

123. Menegon, S.; Columbano, A.; Giordano, S. The Dual Roles of NRF2 in Cancer. Trends Mol. Med. 2016, 22, 578-593. [CrossRef] [PubMed]

124. Atanasov, A.G.; Waltenberger, B.; Pferschy-Wenzig, E.M.; Linder, T.; Wawrosch, C.; Uhrin, P.; Temml, V.; Wang, L.; Schwaiger, S.; Heiss, E.H.; et al. Discovery and resupply of pharmacologically active plant-derived natural products: A review. Biotechnol. Adv. 2015, 33, 1582-1614. [CrossRef] [PubMed]

125. Royston, K.J.; Tollefsbol, T.O. The Epigenetic Impact of Cruciferous Vegetables on Cancer Prevention. Curr. Pharm. Rep. 2015, 1, 46-51. [CrossRef] [PubMed]

126. Tortorella, S.M.; Royce, S.G.; Licciardi, P.V.; Karagiannis, T.C. Dietary Sulforaphane in Cancer Chemoprevention: The Role of Epigenetic Regulation and HDAC Inhibition. Antioxid. Redox Signal. 2015, 22, 1382-1424. [CrossRef]

127. Clarke, J.D.; Hsu, A.; Yu, Z.; Dashwood, R.H.; Ho, E. Differential effects of sulforaphane on histone deacetylases, cell cycle arrest and apoptosis in normal prostate cells versus hyperplastic and cancerous prostate cells. Mol. Nutr. Food Res. 2011, 55, 999-1009. [CrossRef] [PubMed]

(C) 2019 by the authors. Licensee MDPI, Basel, Switzerland. This article is an open access article distributed under the terms and conditions of the Creative Commons Attribution (CC BY) license (http:/ / creativecommons.org/licenses/by/4.0/). 